\title{
The joint consultation of general practitioners and rheumatologists
}

\author{
Citation for published version (APA):
}

Schulpen, G. J. C. (2003). The joint consultation of general practitioners and rheumatologists. [Doctoral Thesis, Maastricht University]. Datawyse / Universitaire Pers Maastricht. https://doi.org/10.26481/dis.20030613gs

Document status and date:

Published: 01/01/2003

DOI:

10.26481/dis.20030613gs

Document Version:

Publisher's PDF, also known as Version of record

\section{Please check the document version of this publication:}

- A submitted manuscript is the version of the article upon submission and before peer-review. There can be important differences between the submitted version and the official published version of record.

People interested in the research are advised to contact the author for the final version of the publication, or visit the DOI to the publisher's website.

- The final author version and the galley proof are versions of the publication after peer review.

- The final published version features the final layout of the paper including the volume, issue and page numbers.

Link to publication

\footnotetext{
General rights rights.

- You may freely distribute the URL identifying the publication in the public portal. please follow below link for the End User Agreement:

www.umlib.nl/taverne-license

Take down policy

If you believe that this document breaches copyright please contact us at:

repository@maastrichtuniversity.nl

providing details and we will investigate your claim.
}

Copyright and moral rights for the publications made accessible in the public portal are retained by the authors and/or other copyright owners and it is a condition of accessing publications that users recognise and abide by the legal requirements associated with these

- Users may download and print one copy of any publication from the public portal for the purpose of private study or research.

- You may not further distribute the material or use it for any profit-making activity or commercial gain

If the publication is distributed under the terms of Article $25 \mathrm{fa}$ of the Dutch Copyright Act, indicated by the "Taverne" license above, 


\section{The Joint Consultation \\ of}

General Practitioners

And

Rheumatologists 
(c) Guy Schulpen, Maastricht 2003.

ISBN 9052783802

The research described in this thesis was performed at the division of Transmural care (BZe VIII) of the academic hospital Maastricht and was embedded in the Research Institute for Extramural and Transmural Care (ExTra), which participates in the Netherlands School of Primary Care Research (CaRe), acknowledged in 1995 by the Royal Dutch Academy of Science (KNAW).

The study is supported by Zorgonderzoek Nederland, Centraal Fonds RVVZ, Raamovereenkomst and Doelmatigheidsfonds.

The publication of this thesis was in particular financially supported by AstraZeneca BV.

Production by Datawyse

Cover design by G. Schulpen \& Datawyse based on a painting by Robert Hinckley. 


\title{
The Joint Consultation of \\ General Practitioners \\ And \\ Rheumatologists
}

\author{
PROEFSCHRIFT \\ ter verkrijging van de graad van doctor \\ aan de Universiteit Maastricht, \\ op gezag van de Rector Magnificus, \\ Prof. dr. A.C. Nieuwenhuijzen Kruseman, \\ volgens het besluit van het College van Decanen, \\ in het openbaar te verdedigen \\ op vrijdag 13 juni 2003 om 12.00 uur \\ door
} Guy Jean Christophe Schulpen

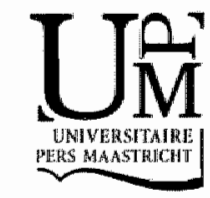


PROMOTOR

Prof. dr. J.M.J.P. van der Linden

Prof. dr. D.M.F.M. vander Heijde

CO-PROMOTOR

Dr. W.P.M. Vierhout

BEOORDELINGSCOMMISSIE

Prof. dr. H.F.J.M. Crebolder (voorzitter)

Prof. dr. P. Pop

Prof. dr. J.M. Hazes (Universiteit Rotterdam)

Prof. dr. J.F. Metsemakers

Prof. dr. T.B. Voorn (Universiteit Utrecht) 


\section{Contents}

Chapter 1

page 8

Introduction

Chapter 2

page 17

Joint consultation of general practitioner and rheumatologist: Does it matter?

Chapter 3

page 29

The value of joint general practitioner and rheumatologist consultations in primary care patients.

Chapter 4

page 41

Patients, general practitioners and specialists: To communicate or not to communicate.

Chapter 5

page 53

Patients at the outpatient clinic of rheumatology: Do they really need to be there?

Chapter 6

$$
\text { page } 63
$$

Joint consultation of general practitioners and theumatologists: Cost minimisation analysis of interdisciplinary collaboration.

Chapter 7

page 81

The win-win consultation. Transmural collaboration between specialist and general practitioners.

Chapter 8

page 89

Discussion

Samenvatting

Dankwoord

Curriculum Vitae 

Research is to see what everybody else has seen, and to think what nobody else has thought

(Albert Szent-Györgi 1893-1986) 

Chapter 1

\author{
Introduction
}


Health care is complex, dynamic and sometimes difficult to survey.

Ideally, we try to deliver the best possible health care to all patients with limitless resources. Unfortunately, this basic goall is not and can not be achieved because of different sorts of limitations. What are some of the more important limitations that we are faced with (especially in relation to Dutch health care)?

In the Dutch health care system, general practitioners (GPs) play an important role. Basically all patients visit the GP first for their complaints and it is the GP who decides if a referral to a specialist or other health care providers is required. This gatekeeper role makes the GP the pivot in health care delivery. Both from a medical point of view as from a societal perspective, this role implies a constant compromise; avoiding unnecessary referrals improves the accessibility of secondary health care, who are nowadays faced with long waiting lists. On the other hand, aiming for quality in medical care, specialists are sometimes required. This results for the GPS in a constant deliberation on whether or not to treat independently, or to refer in some cases. Developments like the ageing of the population, increasing therapeutic possibilities and limited budgets in health care make this deliberation of GPs even more important.

In the Dutch health care system, GPs not only work apart from the secondary health care proverbially, but also literally. GPs have practices in the region apart from the hospital and more often than not, only communicate with their secondary health care colleagues through referral letters. This barrier which has been created over the last decadles makes the gatekeeper role even more difficult. When aiming for optimisation of health care, it seems logical to aim for a model, which improves the collaboration of GPs and specialists. A closer collaboration could support the gatekeeper role and lead to better quality of care.

We will show in this thesis how some of the mentioned factors indeed were influenced by a new model of delivering health care; Joint Consultation.

Firstly, what is Joint Consultation?

By definition, Joint Consultation is a model of collaboration between general practitioners (GPs) and specialists. The principal aim is to improve communication between medical professionals in primary and secondary health care and at the same time to educate GPs through this collaboration. As it turned out, this Joint Consultation had effects that even went beyond that primary goal.

How does it work in practice?

Participating GPs are divided into groups of three GPs. One of the three GP5 will act as host GP. During a set time period (mostly 4-6 weeks), these GPs encounter during their daily work patients they want to refer or where they experience problems in diagnostic and/or therapeutic policy. After these 4-6 weeks, the GPs will gather at the practice of the host GP and they will be visited by a specialist. The cases the GPs gathered are presented to the specialist (in the 
presence of the patient) and the specialist gets the opportunity to take history and examine the patient (together with the GPs present). Finally, the specialist will formulate a policy together with the GP. This policy might include the possibility that the GP will treat the patient independently, that the patient will be re-invited to another Joint Consultation session or that the patient will be referred to the outpatient clinic. It should be noted that until the patient is referred to the outpatient clinic, the specialist acts as consultant and the GP is primarily responsible for the patient. The primary hypothesis is that GPs and specialists communicate better in Joint Consultation and that GPs learn from the specialist. GPs present cases from their own practice with which they have a problem and the specialist shows for these cases what should have been the policy in specialised care settings. In short, this can be considered true problem based learning (1).

This concept was first designed by Vierhout, who tested this for the field of orthopaedic surgery. Vlek tested the model next for the field of cardiology and Bullens for the field of dermatology (2-5). The findings from these studies were very promising and confirmed the hypothesis that GPs indeed learn from Joint Consultation; GPs indicated to have gained in skills and knowledge, referred less patients and participants were satisfied (both patients and physicians).

In 1998 the randomised study "Joint Consultation general practitionerrheumatologist" started. Several differences in design can be distinguished between this design and previous studies. Firstly, rheumatological complaints have a more chronic character, which makes the patient population altogether different from past studies. Secondly, the participating GPs could only include patients into the study if they wanted to refer that patient (control group patients were referred to the outpatient clinic). In other words, Joint Consultation substituted regular referrals, whereas in the previous studies GPS could also include patients if they had a problem or question.

Thirdly, we added a new component to the Joint Consultation model, namely the so-called "referral back". The previous studies only focussed on influencing competence and behaviour of GPs. The referral back focussed on influencing patient flows at a secondary health care level. The hypothesis was that of those patients who were receiving specialist follow-up at the outpatient clinic, some absolutely required that follow-up, some could be discharged from the outpatient clinic soon after referral if there was no additional value in the followup, but also some patients would require follow-up, yet a specialist had no additional value in the follow-up. In other words a (skilled) GP could also perform the follow-up for that patient. 
The consequence would be that the outpatient clinic would be relieved of some patients, which would enhance the accessibility.

How does referral back work?

An overview was supplied by the hospital of all patients of the 17 participating GPS who were referred at some point in time to the outpatient clinic of rheumatology. Their patient charts were marked and when during a follow-up consultation, rheumatologists were confronted with such a marked chart, they would assess whether or not that patient was eligible for referral back. Reasons were documented if patients were not considered eligible.

When eligible, patients were randomised after informed consent. The control group continued to receive follow-up at the outpatient clinic. The intervention group was referred back to the GP who had referred that patient originally to the outpatient clinic. Using the next Joint Consultation session, the consulting rheurnatologist presented the patient (in the presence of the patient) to the GP using the patient chart (and a discharge letter from the rheumatologist who treated the patient at the outpatient clinic). The GP would be advised on the policy for that particular patient. From that moment on, the GP would be responsible for the medical care. If at any time GPS would encounter problems in the follow-up, Joint Consultation sessions could be used to consult the irheumatologist or a patient could be referred to the outpatient clinic.

For both the Joint Consultation as the referral back model, the following research questions have been formulated:

1. Are general health, pain experience and rheumatological complaints of the patient intervention groups comparable to the patient control groups?

2. Is it feasible from a practical, logistical point of view to deliver care by a Joint Consultation and Re-referral?

3. What are the effects for the patient in this new model?

4. What are the effects for the general practitioners in this new model?

5. What are the effects for the rheumatologist in this new model?

6. What are the effects for the general health care system (costs) in this new model?

The first 2 research questions are postulated as a condition sine qua non. They are both of essential value in determining the success of the intervention. Both need to be evaluated positively before one can look into the other effects.

The latter 4 research questions represent the specific angles of this study; success is defined when the outcome of one research question shows a difference of $20 \%$ in comparison to the control-group and the outcome of the 
other 3 research questions are at least the same as the outcome of the controlgroup.

\section{Thesis structure}

In chapter 2 we will discuss the effects of Joint Consultation on the referral rate of participating GPs as compared to non-participating GPs. The nature of the diagnoses and the composition of the diagnoses categories over time will be shown.

The specific effects on diagnostic and therapeutic behaviour of GPS and rheumatologists, as well as follow-up of rheumatologists are demonstrated in chapter 3. The satisfaction of the patients regarding Joint Consultation or the outpatient clinic of rheumatology and the general health status are presented in chapter 3 as well.

The effects on communication between the health care professionals and the communication between physicians and patients are shown in chapter 4 .

Chapter 5 shows the results of the study on reversing patient flows from the outpatient clinic of rheumatology to the GP using the Joint Consultation session; the "referral back".

Chapter 6 and 7 address the effects for the general health care system.

The costs of Joint Consultation versus the costs of the outpatient clinic are presented in chapter 6.

Chapter 7 reflects on the degree of generalisation of the results. It shows an overview of Joint Consultation over the different studies and discusses the implementation in the form of the Carrousel model with accompanying requirements and limitations.

A general discussion is presented in chapter 8. 


\section{References}

1. Davis $D A$, Thomson $M A_{i}$ Oxman $A D_{*}$ Haynes RB. Changing physician performance. A systematic rewiew of the effect of continuing medical education strategies. Jama 1995;274:700-5.

2. Vierhout WP, Kinottnerus $J_{A}$, van Ooij $A$, Crebolder HF; Pop P, Wesselingh Megens AM, et al. Effectiveness of joint consultation sessions of general practitioners and orthopaedic surgeans for locomotor-system disorders. Lancet 1995;346:990-4.

3. Vierhout WPM. Het Gezamenlijk Consult van huisarts en specialist in de eerste lijn. Amsterdam: Thesis Publishers; 1994.

4. Vhek $\mathbb{H}$. Cardiologue. Joint consultation of general practitioners and cardiologists in a primary care setting. Maastricht: Datawyse; 2000.

5. Vlek JFM, Vierhout WPM, Knottherus JA, Schmitz JJF, Winter J, Wesselingh-Megens AMK, et al. A randomised controlled trial of joint consultations with general practitioners and cardiologists in

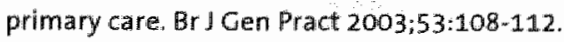






\section{Chapter 2}

\section{Joint consultation of general practitioner and rheumatologist}

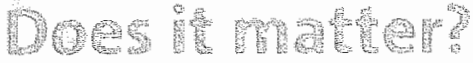

GJC Schulpen, WPM Vierhout, DM van der Heijde, RB Landewé, RAG Winkens, $\mathrm{S}$ van der Linden

Annals of the Rheumatic Diseases. 2003;62:159-61. 


\section{Abstract}

Objective: To assess the effects of Joint Consultation on referral behaviour of general practitioners (GPs) in a prospective cohort study.

Methods: All patients with rheumatological complaints that 17 participating $G P_{5}$, from the area of the University Hospital Maastricht, wanted to refer during a two year inclusion period $(N=166)$ were eligible for inclusion. These patients were either referred to the outpatient clinic, or presented at a Joint Consultation held on a six weekly basis at the practice of the GP, where groups of three GPs presented their patients to a visiting, consulting rheumatologist. The number of patients referred by each GP a year at the end of the trial, comparing participating and non-participating GPS, was the main outcome measure.

Results: During two years of inclusion, the 17 participating GPs presented 166 patients. The number of patients referred by each GP a year decreased for the participating GPs by $62 \%$ at the end of the whole study. By contrast, nonparticipating GPs maintained the same rate of referral. The range of diagnoses remained proportionally the same throughout the study, with the exception of fibromyalgia. The referral rate of this diagnosis decreased significantly $(p=0.001)$.

Conclusions: Joint Consultation seems to be a good strategy in influencing the referral behaviour of GPs in the area of rheumatology. The decrease in referral is substantiall and can subsequently lead to a reduction of waiting lists. 


\section{Introduction}

Doctor's delay and long waiting lists bear the risk of compromising the accessibility and quality of the health care system. In the Netherlands, waiting lists grow constantly. Despite many efforts, no approach has yet been successful in effectively reducing these lists.

In the Dutch healthcare system, patients are generally only admitted to specialised outpatient care after referral by a general practitioner (GP). This implies that the GP, as a gatekeeper, has a strong regulating effect on the influx of patients to outpatient clinics and thereby a great influence on waiting lists (15). At the same time, the GP is primarily responsible for the treatment of the patient. Because of the reduced accessibility to outpatient clinics and the high prevalence of musculoskeletal complaints in the primary healthcare level (15\% of all complaints the GP is faced with (6)), the GP plays an increasingly important part in the treatment of muskuloskeletal complaints.

The performance of GPS and the referral pattern could be improved by further educating GPS, thereby improving their knowledge and skilis. Problem based learning is by far the most effective way of teaching (7-15). Consequently, a model based on problem based learning could have a beneficial effect on rheumatological skills of the GP and on referral and thus on waiting lists, while assuring adequate treatment by the GP (16-19).

We propose Joint Consultation as a model which, through close collaboration between specialists and GPS, meets the requirements for improving rheumatological performance as well as reducing waiting lists.

\section{Methods}

During a period of 2 years (1999-2000), 17 GPs within the region of the University Hospital Mastricht, participated in our randomised trial. The rather isolated geographical position of the hospital created a situation in which patients would almost exclusively be referred to this one hospital. Responding to a questionnaire among all GPS $(N=93)$ in the region, $60(65 \%)$ said to be willing to participate in a Joint Consultation with a rheumatologist. Declining to participate was mostly based on a perceived lack of time. The finall selection of participants was based on availability of GPs for this study and criteria that would match the participants to the general population of referring GPS; 1) practice characteristics (solo, group practice), and location (urban, countryside) and 2) referral behaviour (10-12 referrals to the department of rheumatology by each GP a year). 
Seventeen GPs were selected and agreed to participate (mean age 48.5 years, $12 \%$ women, $47 \%$ rural practice; no significant differences in characteristics were found comparing with non-participating GPS). Referral pattern of the participating GPS matched the referral pattern of non-participating GPS. Thïs overall referral pattern to the outpatient clinic of rheumatology was not influenced by guidelines or educational programs, either before or during the study. There were no reasons to assume that the competency of dealing with musculoskeletal problems of GPs in this region differs from that of other Dutch GPS.

The 43 non-participants who expressed a willingness to participate acted as a control group. The referral rates (and practice/personal characteristics) of nonparticipating GPS who were willing to participate in the study $(\mathbb{N}=43)$ were comparable with those of GPS who declined to participate ( $N=33)$.

All six staff-members of the department of rheumatology were assigned as consultant. Sample size was calculated for a minimal change of $20 \%$ for the primary outcome (which was the referral rate of the participating GPs) and resulted in $N=84 /$ group $(\alpha=0.05$ and $\beta=0.1)$

Any patient the participating GPs wanted to refer had to be included into the study (excluding patients needing emergency referral). After informed consent, the patients entered the study after the GP had received the outcome of the randomisation by telephone. Patients were either referred to the outpatient clinic or they were invited to the next Joint Consultation session (intervention-group). The six-weekly Joint Consultation sessions consisted of three GPS, as well as one visiting rheumatologist, at the practice of a host GP. The GPS presented each patient. Next, the consulting rheumatologist re-examined the patient and formulated a diagnostic and therapeutic policy together with the GP.

The opinion of the rheumatologist was considered as the "gold standard" in the assessment of the diagnoses. "These were divided into five categories by means of the standard diagnoses registration (SDR) form, which is used by most Dutch rheumatologists in the registration of rheumatological diseases at outpatient clinics (20). These five categories consist of arthritis, systemic illness, osteoarthritis, arthralgias, and a fifth category, which was subdivided for the purpose of this study into fibromyalgia (also comprising general pain syndromes) and other diagnoses (including bursitis, tendinitis)). The SDR database supplied data on the overall number of patients with the diagnosis fibromyalgia at the department of rheumatology for our hospital during the years 1995-2000.

Participation in this study would supposedly lead to a change in referral behaviour of the GPs; convenience lavoiding the extra effort of participating in a study) could lead to an increase of referral to other, related, specialists. Therefore, the medical administrative department of the University Hospital Maastricht was requested to supply data on the number of referrals to outpatient clinics of 
internal medicine, neurology, orthopaedic surgery and theumatology for both the 17 participating GP5 and for the remaining 43 non-participating GPS (the control group)

For the analysis of the referral data to the department of rheumatology, 17 non-participating GPS were matched to the participants concerning location (urban-rural), workload (full-time, part-time) and overall referral rate to the outpatient clinic of rheumatology before to the study.

The number of referrals from each GP for the year 2000 was compared with the preceding year (1999) and the difference between the two years was assessed for both the 17 participating GPs and for 17 non-participating GPS using the Mann-Whitney $U$ test. Data on the number of patients referred by each GP for the year 1998 were not available except for group level data. Therefore we chose to compare the first year of the study to the second year of the study.

In the statistical analyses of the diagnostic subcategory fibromyalgia, the variation in the number of diagnoses of fibromyalgia between the 17 participating GPS was taken into account. These data were obtained for two points in time (beginning and end of the study: 1999-2000). As the data from each GP were considered to be related samples, the Wilcoxon Signed rank test was used for this analysis.

The medical ethics committee of the University Hospital Maastricht had approved the study.

\section{Results}

During the two years of the study, 166 patients were included. Twenty-three patients were referred to the outpatient clinic of rheumatology by the participating GPs without entering the study. Declining to participate by the part of the patient $(16 / 23)$ and the GP's opinion that a patient was not suitable for Joint Consultation $(4 / 23 ; 3 / 23$ other reasons), were the main reasons for nonparticipation (mean age 51.2 (SD $=17.8$ ) years; $30 \%$ were men). This nonparticipation was equally spread over the study period ( 24 months). The mean age of the participating patients was 53.7 years $(S D=14.0): 27 \%$ were men.

Before the beginning of the intervention (until 1999) both participating as non-participating GP5 had an increasing yet comparable referral rate to the department of rheumatology. By the end of the study period (2000), the number of patients referred by each GP a year (3.7 patients/GP/year) by the participating GPS differed (-62\%) from the number of patients referred ( 9.7 patients/GP/year) by the 17 matched non participating GPS. We found an average reduction in the referral rate of $-2.8(S D=3.9)$ patients referred for participating GPS when comparing 2000 to 1999 , versus a difference in the referral rate of zero ( $5 D=2.1$ ) 
patients referred for the 17 non-participating GPS, a difference with was significant ( $p=0.024$; Mann-Whitney $U$ test).

This remarkable change was not found for non-rheumatological referrals by the 17 participating GPS (Figure 1).

Figure 1: Proportion of referrals by the 17 participating GPs expressed as a fraction (\%) of all referrals by all 76 nom-participating GPs for internal medicine, neurology and orthopaedic surgery. Note that there is no change after the start of the intervention as of 1999.

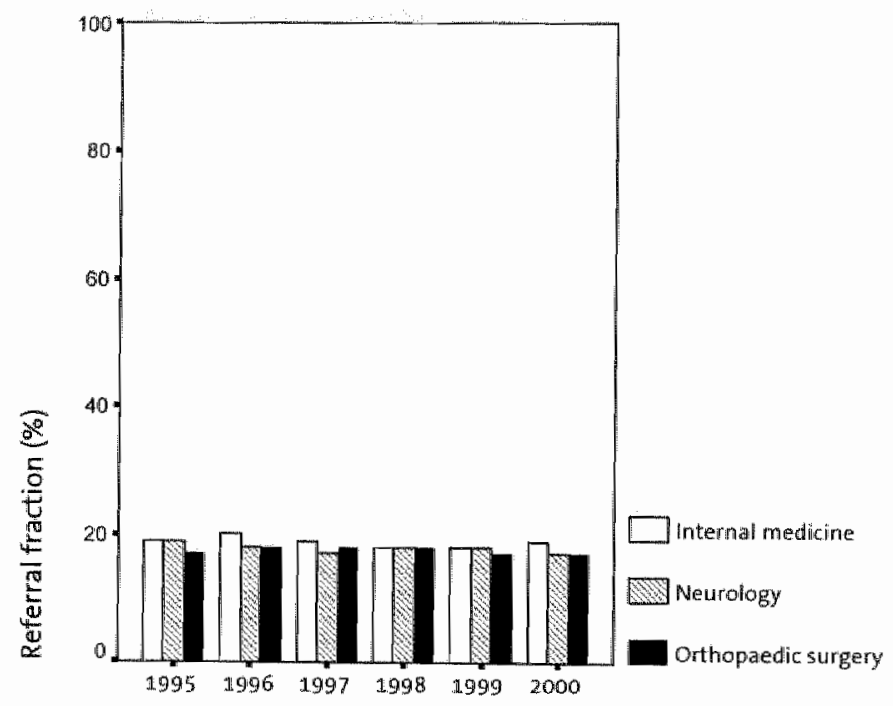

Moreover, we found a shift in the range of diagnoses over time (Table 1). Whereas all the other standard diagnosis registration categories showed no significant change proportionally, the subcategory fibromyalgia showed a significant decrease ( $p=0.001$; Wilcoxon signed rank test), comparing the first year of the intervention (in 1999, 40 out of the 144 diagnosis comprised fibromyalgia) to the second year of the intervention (in 2000, eight out of 72 diagnosis comprised fibromyalgia). 
Table 1. The number of diagnoses in time for each standard diagnoses registration (SOR) category. which consisted of arthritis (1), systemic illness (2), osteoarthritis (3), arthralgias (4), other diagnoses (including burstitis, tendinitis)(5) and fibromyalgia (6). More diagnoses per patient were recorded.

\begin{tabular}{lcc}
\hline & $1999(N=144)$ & $2000(N=72)$ \\
\hline SoR categories & $N(\%)$ & $N(\%)$ \\
1 & $30(21 \%)$ & $18(25 \%)$ \\
2 & $4(3 \%)$ & $5(7 \%)$ \\
3 & $34(24 \%)$ & $13(18 \%)$ \\
4 & $1(1 \%)$ & $3(4 \%)$ \\
5 & $24(17 \%)$ & $15(21 \%)$ \\
$6^{*}$ & $40(28 \%)$ & $8(11 \%)$ \\
\hline
\end{tabular}

* $p=0.001 ;$ Wilcoxon Signed Rank test

The overall number of patients with the diagnosis fibromyalgia (as referred by all 93 GPs from the region) remained stable for the years 1995-2000 (1995: 186 patients, 1996: 192 patients, 1997: 190 patients, 1998: 180 patients, 1999: 208 patients and 2000: 184 patients)

In the two-year study period, 54 Joint Consultation sessions (for 87 intervention group patients) were held with an average of 1.4 hours a session. There were 47 follow-up consultations for this group, with a standard duration of 15 minutes. A primary consultation at the department of rheumatology was standlard 45 minutes (for 79 control group patients) and the 96 follow-up consultations that resulted from these were a standard 15 minutes. This resulted in a total of 87.4 hours invested by the rheumatologists in Joint Consultation versus 83.3 hours in total at the outpatient clinic. For each patient, Joint Consultation takes 1.0 hours versus 1.1 hours for each patient at the patient clinic. If all 166 patients had been examined in Joint Consultation sessions, this would have lead to 144.2 hours of Joint Consultation sessions and 22.5 hours of follow-up consultations, resulting in 166.7 hours in total. If the 17 participating GPs had only referred to the outpatient clinic (and Joint Consultation education had not caused a decrease in referral), 292 would have been referred, based on the referral rate of the 17 participants before to Joint Consultation. These 292 would have taken 219.0 hours of primary consultations and 88.8 hours of followup consultations, resulting in 307.8 hours in total. Joint Consultation would have lead to a decrease of $46 \%$ of the time spent by the rheumatologists. 


\section{Discussion}

In the process of reducing waiting lists, transferring patients from the secondary health care level back to the primary health care level is an often used and important strategy.

Many outpatient clinics have long waiting lists and incur more direct medical expenses compared with primary health care. Therefore, preventing access to specialist care or transferring patients to primary care seems a logical solution. There are, however, some specific aspects that have to be taken into consideration.

Firstly, the level of knowledge and skills of a specialist is not straightforwardly comparable with that of a GP. In Joint Consultation however, the patient is primarily treated by the GP, but the specialists' skills are transferred as well to the primary health care level. Therefore, the standard of medical care will not be compromised in any way.

Secondly, the daily workload of GPs increases steadily, which makes any extra burden not very attractive at first sight. Although Joint Consultation may lead to an increased patient workload for the GP, we think that a skilled and confident GP ultimately needs less time and effort to treat comparable patients. Improving the ability to treat confidently more patients appropriately with a certain ailment does not automatically imply a larger workload, especially not in the long-term. The large decrease in the number of patients referred with fibromyalgia (which was not found in non-participating GPs) supports this view. Fibromyalgia is a condition that can be diagnosed and treated adequately by a skilled GP.

The impact of Joint Consultation rheumatology on referral behaviour is substantial ( $62 \%$ decrease in referrals by the end of the study). The nonparticipating GPS maintained a constant high level of referrals throughout the duration of the study. Also, adjacent medical fields such as internal medicine, neurology, or orthopaedic surgery showed no change in referral rate by the participating GPs. Hence, it seems reasonable to attribute the decrease in referral rate for the outpatient clinic of rheumatology to the Joint Consultation intervention. Moreover, the decrease in referral for the participating GPS seemed specific for rheumatology, and is supposedly not a manifestation of a general trend of decrease in referral rate by the participating GPs.

A reduction in referral of the magnitude accomplished in this study seems promising for a long-term evaluation of the Joint Consultation as a joint care model. This is confirmed by study of the time invested by the participating rheumatologists. Because of the large decrease in follow-up consultations after Joint Consultation (and the decrease in referrals due to participation in Joint Consultation), there is "time-effectiveness" compared to the time invested at the 
department of rheumatology. Seemingly labour-intensive, Joint Consultation apparently does not take up more time.

Obviously, other aspects have to be taken into consideration before any definitive conclusions can be drawn. Cost assessment, durability of the effects, long term evaluation of the opinion of all stakeholders, and also qualitative and quantitative assessment of diagnostic and therapeutic performance are among the issues that need to be considered in detail. Provided that these issues accord with the reported results, Joint Consultation would be an important step in diminishing the waiting list problem while simultaneously assuring rheumatological care for patients with these highly prevalent diseases. 


\section{References}

1. Blaauw $A A_{\text {, }}$ Schuwirth $L W$, van der Vleuten $C P$, Smits $F$, van der Linden $S$. Assessing dinical competence recognition of case descriptions of rheumatic diseases by general practitioners. $8 \mathrm{r} J$ Rheumatol 1995;34:375-9.

2. Jones Elwyn $\mathrm{G}_{x}$ stott $\mathrm{NC}$. Avoidable referrals? Analysis of 170 consecutive referrals to secondary care. BM 1994;309:576-8.

3. Knottnerus JA, Joosten J, Daams I. Comparing the qualify of referrals of general practitioners with thigh and awerage referral rates: an independent panel review. Br J Gen Pract 1990;40:178-81.

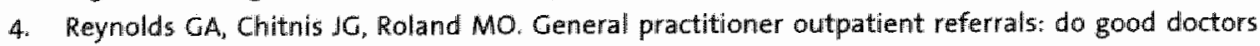
refer more patients to hospital? BMJ 1991;302:1250-2.

5. Walker Dy, Griffiths ID, Leon CM. Referrals to a rheumatology unit: an evaluation of the views of patients, general practitioners, and consultants. Ann Rheum Dis 1991:50:926-9.

6. Lamberts $\mathrm{H}$. In het huis van de huisarts: verslag van het Transitieproject (The Transition model in general practice.). Lelystad: Meditekst; 1991.

7. Branch WT. Primary care practice and training in theumatology. Arthritis Rheum 1994;37:305-6.

8. Brooks PM. Rheumatology training for general practice. J Rheumatol 1999;26 Suppl 55:58-9.

9. Cantillon $P$, Jones $R$. Does continuing medical education in general practice make a difference? BMJ 1999;318:1276-9.

10. Doherty $M$. Lanyon P. Rheumatology: what should all doctors know? Ann Rheum Dis 2000;59:409-13.

11. Grahame $R$, Gibson $T$, Dale $E_{x}$ Anderson $J A$, Brown $R_{a}$ Higgins $P$, et al. An evaluated programme of rheumatology training for general practitioners. Br J Rheumatol 1986;25:7-12.

12. Hasman A. Education of health professionals. 5tud Health Technol Inform 1993:51:41-4.

13. Hosie CA. Teaching rheumatology in primary care. Ann Rheum Dis 2000;59:500-3.

14. Hull SA. Rheumatology education for general practice. Ann Rheurm Dis 1991;50 Suppl 3:449-52.

15. Lanyon $P$, Pope D, Croft P. Rheumatology education and management skills in general practice: a national study of trainees. Ann Rheum Dis. 1995:54:735-9.

16. Bailey JJ, Black ME, Wilkin D. Specialist outreach clinics in general practice. BMJ 1994;308:1083-6.

17. Gjelle A. Primary care and rheumatology in musculoskeletal disorders: bridging the gap. J Rheumatol 1996;23:205-7.

18. Pop $P$, Winkens $\mathbb{R} A$. A diagnostic centre for general practitioners: results of individual feedback on diaghostic actions. JR Coll Gen Pract 1989;39:507-8.

19. Vierhout WPM, Knottnerus JA, van Ooil A, Crebolder HFJM, Pop P, Wesselingh-Megens AMK, et all. Effectiveness of joint consultation sessions of general practitioners and orthopaedic surgeons for locomotor-system disorders. Lancet. 1995:3:46:990-4.

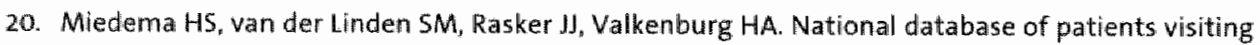
rheumatologists in The Netherlands: the standard diagnosis register of rheumatic diseases. A report and preliminary analysis. Br I Rheumatol 1998:37:555-61. 




\section{Chapter 3}

The value of joint general practitioner and rheumatologist consultations in primary care patients

GIC Schulpen, WPM Vierhout, DM van der Heijde, RB Landewé, S van der Linden, RAG Winkens.

Nederlands Tijdschrift voor Geneeskunde. 2003;147:447-50. 


\section{Abstract}

Objective: To compare the effects of regular referral by general practitioners to the rheumatology outpatients' clinic whit that of Joint Consultations by general practitioners (GPs) and rheumatologists, and to compare the subsequent treatment policy followed.

Design: Randomised.

Methods: In 1999 and 2000 all rheumatological patients who according to the 17 participating GPs in the Maastricht region had an indication for referral, were referred to the outpatient clinic or seen during a Joint Consultation where three GPs and one rheumatologist decided on a treatment policy in the presence of the patient. Agreement about diagnosis and diagnostic and therapeutic approaches between rheumatologists and GPs was determined using questionnaires. The patient's state of health was assessed using the 'EuroQol health-related quality of life questionnaire' (EuroQol) and their satisfaction was determined by means of questionnaires.

Results: One hundred and sixty-six patients were included: 45 (27\%) men and $121(73 \%)$ women, with an average age of 53.7 years $(S D=14)$. The rheumatologists and the GPs differed in opinion on the diagnosis in $64 \%$ of the patients. Agreement on diagnosis resulted in greater agreement on the treatment policy than when there were discrepancies about the diagnosis. The rheumatologist used additional diagnostic tools and follow-up consultations at the outpatient clinic ( $78 \%$ and $65 \%$ ) more frequently than during the Joint Consultation ( $44 \%$ and $15 \%)$. Patient satisfaction and health status were comparable in both groups. 


\section{Introduction}

Better collaboration between primary and secondary health care is an important requirement to make health care more effective and to improve quality of care. Joint Consultation is a model of collaboration between general practitioners (GPS) and specialists. This collaboration consisted of three GPS and a visiting rheumatologist: once per six weeks they would discuss the cases of referred rheumatological patients, who were present as well.

The hypothesis was that through this intensive form of collaboration, physicians not only communicated better, but also learned from each other. The participating GPs learned from the specialist to deal independently with simillar problems in future cases. This should be visualised in the number of patients referred by the GPs. And indeed this resulted in $62 \%$ less referrals from participating GPs in comparison to matched non-participating GPs (1). This decrease concurred with previous experiences on the field of orthopaedic surgery and cardiology (2-4).

The question was whether Joint Consultation merely had an effect on the quantity of referrals or that other effects could be assessed. Possibly specialists could learn from GPs as well? What were the consequences for the patients?

In the here presented study, we compared the effects of regular referral of GPs to the department of rheumatology with referral to the Joint Consultation and the subsequent policy.

\section{Methods}

During a period of 2 years (1999-2000), 17 GPs within the region of the University Hospital Maastricht, participated in this study. In a questionnaire among all regional GPs $(\mathbb{N}=90)$ in the region, $66 \%$ of the GPs stated to be willing to participate in a Joint Consultation with a rheumatologist. Refusal to participate was predominantly based on lack of time. The final selection of participants was based on availability of GPs for this study and criteria that would match the participants to the general population of all referring GPS: 1) practice characteristics (solo, group practice), and location (urban, rurall), and 2) referral behaviour (10-12 referrals per GP per year). The seventeen participating GPs matched the general population of GPs on aforementioned criteria. All six staff-members of the department of rheumatology were assigned as consultant.

Any patient the GP wanted to refer could be included into the study (excluding patients needing emergency referral). After informed consent, the patients entered the study after the GP had received the outcome of the 
randomisation by telephone. Patients were divided in intervention or control group. Control group patients were referred to the outpatient clinic in the usual way. The intervention group patients were invited for the next Joint Consultation.

A Joint Consultation session consisted of a fixed group of three GPs, as well as one visiting rheumatologist, at the practice of a host-GP. On a six-weekly basis (and during the course of the study, based on the number of patients) the GPs presented their patients, after which the consulting rheumatologist re-examined the patient and formulated a diagnostic and therapeutic policy together with the GP. This policy could be that the GP handled follow-up independently, that the patient would be re-invited to a Joint Consultation session or that the patient would be referred to the outpatient clinic.

Diagnostic and therapeutic actions of both GP and rheumatologist (during the primary consultation of the GP and after Joint Consultation or a consultation at the outpatient clinic) were recorded by questionnaires. The concordance between GPs and the rheumatologist regarding diagnostic and therapeutic policy was assessed using these questionnaires. The rheumatologists could also indicate in these questionnaires if they found the diagnosis or the policy, whether diagnostically or therapeutically, significantly changed. The EuroQol was used for the general health status of the participating patients. This test was performed on a monthly basis until one year of follow-up after inclusion. The range of the EuroQol varies from maximally 1 to minimally $-0.59(5,6)$. Patient satisfaction was recorded by questionnaires $(2,3)$. The comparisons between Joint Consultation and the outpatient clinic were analysed using Chi-Square tests.

The medical ethical committee of the University Hospital had approved the study.

\section{Results}

During the 2 years of the study, 166 patients were included (mean age: 53.7 years $(\mathrm{SD}=1.4) ; 45(27 \%$ male) and $121(73 \%)$ female). Seventy-nine $(48 \%)$ were referred to the outpatient clinic (control group) and $87(52 \%)$ were discussed during a Joint Consultation (intervention group)

General practitioners

For 119 of the 166 patients (72\%), the GP used diagnostic tools. These consisted primarily of radiological and/or laboratory requests (148/161 diagnostic requests $(92 \%)$ ). The amount of diagnostic tools used by the GPs prior to Joint Consultation sessions did not differ from the amount used prior to referral to the outpatient clinic (data not shown) 
Figure 1 shows the decreasing number of patients referred by the participating GPs during the two years of the study (1999-2000). After two years, the participating GPs referred $62 \%$ less patients than a group of matched nonparticipating GPs.

Figure 1: The number of patients referred by the 17 participating GPS during the two year inclusion period (1999-2000) and the level of concordance between C.P and theumatologist regarding the diagnosis.

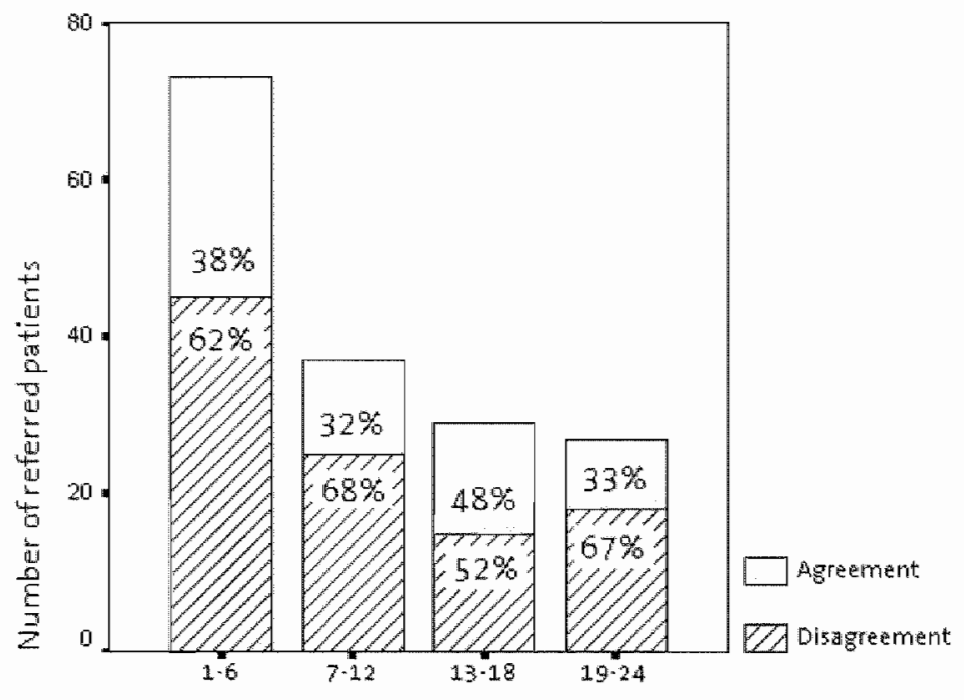

Indusion period (months)

When assessing the diagnoses, the rheumatologists did not concur with the GP in $64 \%$ on average (107/166) of all cases (according to the rheumatologist, the diagnosis was significantly changed). This disagreement on the correct diagnosis remained proportionally the same throughout the study period, whereas the absolute number of patients decreased. In 91/107 (85\%) of all cases during Joint Consultation, the GP agreed with the rheumatologist that the diagnosis was changed significantly. Main reasons for changing diagnoses were patient history (40/107; $37 \%)$, physical examination $(44 / 107 ; 41 \%)$, radiological or laboratory findings $(11 / 107 ; 10 \%)$, more specialist knowledge and skills of the rheumatologist $(21 / 107 ; 20 \%)$ and other reasons $(10 / 107 ; 9 \%)$ (more answers were allowed).

The therapy of the GPs until inclusion as well as therapeutic actions of the rheumatologists after Joint Consultation or a consultation at the outpatient clinic, are shown in Figure 2. 
Especially the categories 'medication' and 'physiotherapy' differed between GPs and rheumatologist5. When the GP had prescribed medication, the rheumatologist also prescribed medication in $49 \%$ (55/113) of the cases (of these were $45 \%$ NSAIDs) versus $29 \%(10 / 34)$ when the GP had not prescribed medication (of these were $80 \%$ NSAIDs).

Figure 2: The diagnostic actions of the GP pricr to referral (so prior to inclusion into the study) and the diagnostic actions of the rheumatologist at either the outpatient clinic or Joint Consultation. More ariswers were allowed. No significant difference was observed between intervention and control group.

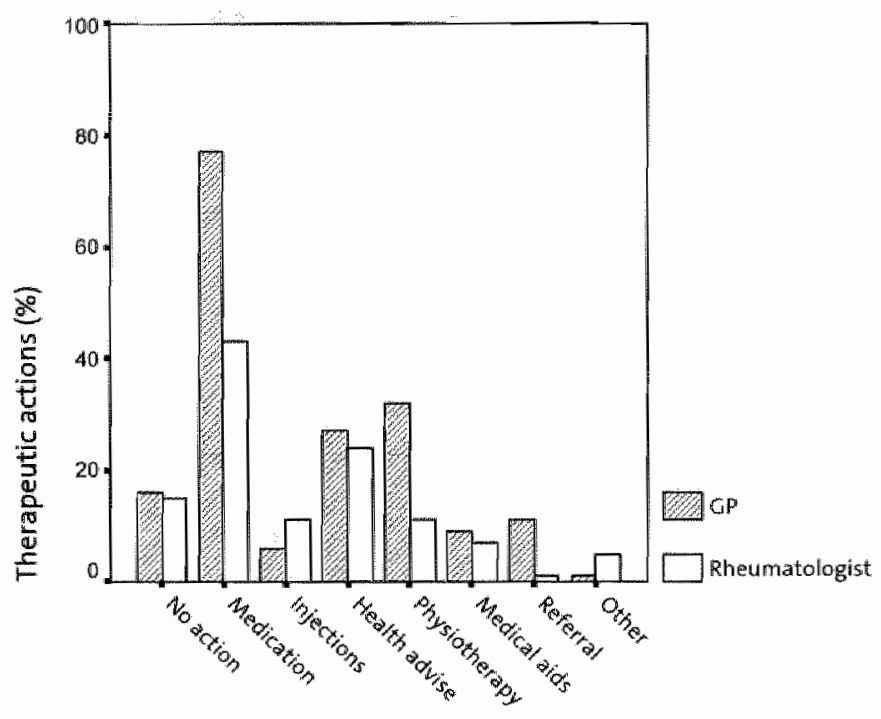

When the rheumatologist disagreed with the diagnosis of the GP, the rheumatologist often disagreed on the therapy of the GP $(75 \% ; 69 / 92)$ (table 1). When the rheumatologist considered the diagnosis correct, the difference of opinion regarding therapy was considerably lower $(53 \% ; 31 / 58 ; p<0.01)$.

In conclusion, agreement on diagnosis was associated with a higher degree of agreement on therapy.

Rheumatologists

The rheumatologists indicated during Joint Consultation sessions not to need diagnostic tools in $46 / 82$ cases (56\%) versus $15 / 69$ (22\%) cases at the outpatient clinic ( $p<0.001$; incomplete data $N=15(9 \%)$ ).

Consequently, if diagnostic tools were used $(\mathrm{N}=90)$, more diagnostic tools were used at the outpatient clinic $(p=0.04)$ : radiological requests: $21 / 36(58 \%)$ during Joint Consultation versus $39 / 54(72 \%)$ during the consultation at the 
outpatient clinic; laboratory requests: $23 / 36(62 \%)$ during Joint Consultation versus $42 / 54(78 \%)$ during the consultation at the outpatient clinic. The majority of the diagnostic requests consisted of radiological or laboratory requests ( $84 / 91$; $92 \%)$.

Concerning therapy, no significant differences were observed between the therapy of rheumatologists at the outpatient clinic versus Joint Consultation (data not shown).

The follow-up policy of the rheumatologists, however, did differ. The consultation during a Joint Consultation session or the first consultation at the outpatient clinic was considered a first consultation. Remarkably, single consultations by the rheumatologists occurred in 69/81 (85\%) of the cases during Joint Consultation versus $24 / 69(35 \%)$ single consultations at the outpatient clinic $(p<0.001)$.

\section{Patients}

No significant difference for the average health status (as assessed by the EuroOol) between patients at the outpatient clinic (0.57; SD:0.04) versus patients of Joint Consultation (0.64; SD: 0.04) was observed after 1 year follow-up.

The satisfaction of the patients assessed after Joint Consultation did not differ from the satisfaction of patients assessed after the consultation at the outpatient clinic. ( 52 of the $80(65 \%)$ patients indicated to be satisfied after Joint Consultation versus $46 / 69(71 \%)$ at the outpatient clinic; for 7 intervention group patients and for 10 control group patients data were missing).

Table 1: The number of patients with whether or not agreement between GP and rheumatologist on the concerned diagnosis and therapeutic policy*"

\begin{tabular}{lllll} 
& & \multicolumn{3}{c}{ Therapeutic policy } \\
\cline { 2 - 4 } & & Agree & Disagree & Total \\
\cline { 2 - 5 } Diagnosis & 27 & 31 & 58 \\
& Agree & 23 & 69 & 92 \\
& Disagree & 50 & 100 & 166 \\
\hline
\end{tabular}

"Of 16 patients data were incomplete 


\section{Discussion}

Joint Consultation is a transmural model through which physicians learn from each other through close collaboration. This results for GPs in an increase in their problem solving capacity, because of which the influx of patients decreased. This is illustrated by fibromyalgia, a condition which can be treated by a educated, experienced GP. Especially this condition decreased the most in the referral rates. Being taught by the specialist what should have been done with a referred patient, the GP learns to deal with similar problems independently in the future. This is reflected in the decrease of the number of patients referred by the 17 participating GPs in comparison to 17 matched non-participating GPS $(62 \%)(1)$

The large discrepancy between diagnoses of GPs and rheumatologists shows at the same time, that there is ample room for improvement. The fact that this discrepancy (proportionally) remains is not illogical, because, when GPs do not come to a solution independently, it will concern "more difficult" cases. The difference in therapeutic policy can be explained by the fact that GPs are starting their therapeutic policy earlier in the disease process and that apparently the therapy failed to render success (after all the GP referred the patient). A final observation for the GPS is that a correct diagnosis leads to a correct therapy. This may seem logical but the primary health care approach of morbidity is often focussed on complaints rather than diagnosis (GPS use e.g. the "International classification of primary care (ICPC), which describes complexes of complaints). Perhaps a more diagnosis-focussed approach should be preferred.

It turns out that not only GPS adapt their behaviour, but also specialists demonstrate a clear difference in behaviour between the outpatient clinic and Joint consultation. This was particularly obvious concerning the diagnostic and follow-up policy.

Fewer diagnostic tools were used and fewer consultations were required. Here also, there are many possible explanations such as the expectations of patients toward the hospital, the routine at the outpatient clinic and medical responsibility which the GP had during Joint Consultation. These explanations are indicated by the rheumatologists in the final analysis of the study. Nevertheless, the rheumatologists showed they needed far fewer diagnostic tools and far fewer consultations to still provide adequate medical care (the health status of the patients from Joint Consultation were comparable with the health status of those from the outpatient clinic). Perhaps that the practical, primary care way of handling things, stimulated the specialists to use time and means critically. At 
any rate, these findings provide just cause for discussion on the necessity of some actions at the outpatient clinic.

The effects of Joint Consultation concerned both GPs and specialists. Joint Consultation in this shape is not just a unique theoretical concept, but turns out to be feasible and effective at many levels. One issue we have not debated yet and which is an important requirement, is an analysis on costs. This analysis will have to compare the extra time and effort invested by the participating physicians to the savings in referrals, in the amount of follow-up consultations and in the amount of diagnostic tools (1). Regarding the educational effects for GPs and specialists and subsequently the effects of the quality of health care delivery, it appears that the results justify a placement of Joint Consultation in the regular health care, which has been effectuated in the meantime for the region of Maastricht. 


\section{References}

1. Schulpen $G M$, Vierhout WPM, van der Heijde DM, Landewé RB, Winkens RAG, WesselinghMegens AMK, et al. Joint Consulltation of General Practitioner and Rheumatologist: Does it matter? Ann Rheum Dis 2003;62:159-61

2. Wierhout WPM. Het Gezamenlijk Consult van huisarts en specialist in de eerste lijn. Amsterdam: Thesis Publishers; 1994.

3. Vierhout WPM, Knottnerus A $_{\text {; }}$ wan Ooij A, Crebolder HFMM, Pop P, Wesselingh-Megens AMK, et al. Effectiveness of joint consultation sessions of general practitioners and orthopaedic surgeons for locomotor-system disorders. Lancet 1995;346:990-4.

4. Wlek JFM. Cardialogue, Joint consultation of general practitioners and cardiologists in primary care setting. Maastricht: Datawyse; 2000

5. Essink Bot ML. Stouthand ME, Bonsel GJ. Generalizability of valuations on health states collected with the Euroqolc-questionmaire. Health Econ 1993:2:237-46.

6. Hurst NP, Kind P, Ruta D, Hunter M, 5tubbings A. Measuring health-related quality of life in rheumatold arthritis: validity, responsiveness and reliability of EuroQol (EQ-5D). Bir \& Rheumatol $1997 ; 36: 551-9$. 




\section{Chapter 4}

\section{Patients, general practitioners and specialists}

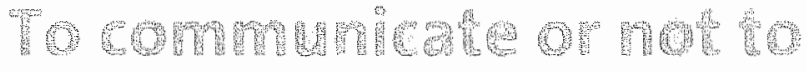

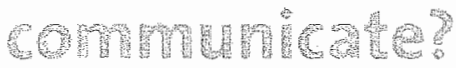

GJC Schulpen, WPM Vierhout, DM van der Heijde, RB Landewé, $S$ van der Linden, AMK Wesselingh-Megens, RAG Winkens.

Submitted 


\section{Abstract}

Communication between doctors amongst themselves as well as between doctors and patients is regularly not optimal and the importance is often underestimated. Poor reassurance increases demand from patients. Poor communication between doctors impedes with quality of health care when transferring patient care. Joint Consultation is a form of collaboration between general practitioners (GPS) and specialists. Though not suitable for every health care system, it is illustrative for improvement of communication through better collaboration. Recent developments as shared care and disease-management could benefit from these findings. 


\section{Introduction}

Primary and secondary health care often communicate poorly (1-6). On the other hand, doctors and patients often also lack adequate communication. General practitioners (GPs) regularly refer patients to specialists without detailled information on the medical background of the patient or the specific reasons for referring the patient. Specialists often do not provide adequate feedback on the referral of GPs and the subsequent treatment at the outpatient clinic. Even when discharging patients from the hospital to the care of the GP, adequate information sometimes fails. In the face of developments as diseasemanagement and shared care, communication is of vital importance when transferring patient care from one health care provider to another.

Not only the doctors amongst themselves communicate less than optimal. Patients and doctors lack mutual understanding as well. Patients may not get their specific wishes and worries across to the physician. Patients who are not satisfied with their treatment, or who are still apprehensive, may seek more medical consulting than those who are reassured and satisfied with their treatment. Although communication in itself is not a goal, it can be a tool in the treatment of patients (7).

In Joint Consultation, GPS work closely together with specialists and this offers an opportunity to enable a better communication between GPs and specialists. Basically, Joint Consultation aims at improving the knowledge and skills of GPs. By seeing patients together with specialists, GPs learn from the cases they themselves provide. This results in better care at a primary care level and leads to a decrease in referral by participating GPs of $62 \%$ and improves diagnostic behaviour $(8,9)$.

We studied communication between the participating parties: patients, GPs and specialists within the scope of a trial on Joint Consultation between GPs and rheumatologists. Musculoskeletal ailments are common in the GP practice and the communication dynamics involved, probably reflect dynamics in other fields of medicine. Therefore, we believe that our findings regarding communication although obtained from a study on selected cases (with rheumatological problems)- can largely be extrapolated to a general perception of communication.

Our hypothesis is that both GPS and rheumatologists do not perceive all signals their patients try to give. The second hypothesis is that GPS and rheumatologists communicate better when they are working together in the same room. They will appreciate each other's point of view more easily and they have a better opportunity to exchange important background information. 


\section{Methods}

During a period of 2 years (1999-2000), 17 GPs within the region of the University Hospital Maastricht, participated in a randomised controlled trial on Joint Consultation. Responding to a questionnaire among all GPs $(N=90)$ in the region, $66 \%$ of the GPS said to be willing to participate in a Joint Consultation with a rheumatologist. Declining to participate was predominantly based on lack of time. We selected available participants on criteria matching the participants to the general population of referring GPS: 1) practice characteristics (solo vs. group practice, urban vs. rural) and 2) referral behaviour (10-12 referrals per GP per year). Seventeen GPs met these criteria. All six staff-members of the department of rheumatology were assigned as consultant.

Any patient the GP wanted to refer could be included into the study (excluding emergencies). After informed consent, patients were either randomly referred to the outpatient clinic (control-group), or they were invited to the next Joint Consultation session (intervention-group). A Joint Consultation session was held on a 6 weekly basis and consisted of three GPs; as well as one visiting rheumatologist, at the practice of a host-GP. The GPS presented their patients, after which the consulting rheumatologist re-examined the patient and formulated a diagnostic and therapeutic policy together with the GP. The reported data were collected through questionnaires $(8,9)$ at several moments: at entering the study (after the initial consultation at the GP's practice) and at the following consultation with the rheumatologist (at the outpatient clinic for the control group patients or at the Joint Consultation for the intervention group patients).

Tables $1 \mathrm{~A}$ and $1 \mathrm{~B}$ show the items in the questionnaires for the patients, the GPs and the rheumatologists. 
Table 1A: The items in the questionnaires for patients after their consultation with the GP (and after the consultation with the rheumatologist) and the items for the GP. The answers are added in italic

\begin{tabular}{|c|c|c|}
\hline & Patient & $G \mathrm{p}$ \\
\hline \multirow[t]{26}{*}{ After first consultation } & How serious da you consider your & How ser irous do you thangh the \\
\hline & complaint? & patient considers his her \\
\hline & (3 paint scale: Vey serious-Not so & complaint? \\
\hline & serious - Not serious at ally & (4 point scale: Very serious-Not so \\
\hline & & serious-Not serious at all-No \\
\hline & & opinion) \\
\hline & Are you concerned about your & Do you feel the patient has many \\
\hline & complaint? & concerns about histher complatnt? \\
\hline & (3 point scale: Yes, a hot-Yes, a & (apoint scale: Yes, a lot-Yes, a \\
\hline & !ittle-No! & (ittle-Nol \\
\hline & What did you want your GP to do & What is the reason according to \\
\hline & about the camplaint? & you that the patient vasited you? \\
\hline & (multiple answers allowed: Treat & (multiple answers allowed: \\
\hline & independentlyanvestigate. & Reassurance Therapy by yoursalf. \\
\hline & Reassure Refer to speciallist-Refer & Referral to specilalistumeferral to \\
\hline & to (physiolitherapist-Other-Wo & (physio)therapist-other-No \\
\hline & opinion) & opinion \\
\hline & Are you reassured? & \\
\hline & 3 point scale: Completelly. & \\
\hline & Somewhat-Not) & \\
\hline & Did you get enough attention? & \\
\hline & 3 point scale: Completely. & \\
\hline & Somewhat- Wot) & \\
\hline & Did you get enough explanation? & \\
\hline & 3 point scale: Completely. & \\
\hline & Somewhat-Not) & \\
\hline \multirow{9}{*}{$\begin{array}{l}\text { After consultation with } \\
\text { rheumatologist }\end{array}$} & Are you reassured? & \\
\hline & 3 point scale: Complettely & \\
\hline & Somewhat-Mot) & \\
\hline & Did you get enough attention? & \\
\hline & 3 point scale: Completely. & \\
\hline & Somewhat-Not) & \\
\hline & Did you get enough explanation? & \\
\hline & 3 point scale: Completely. & \\
\hline & Somewhat-Not) & \\
\hline
\end{tabular}




\section{Table 18}

The items in the questionnalres for the CPS after the first consultation and the items for the theumatologists after consultation (at either Joint Congultation sessions or at the outpatient clinic). The answers are added in italic.

\begin{tabular}{ll}
\hline GP & Rheumatologist \\
\hline What was your reason for referring this & What was according to you the reason for \\
patient to the outpatient clinic? & the GP to refer this patient \\
(Multiple answers allowed: Uncertainty & (Muitiple answers allowed: Uncertainty \\
diagnosis-Uncertainty policy-Reassurance- & diagnosis-Uncertainty policy-Reassurance- \\
On request patient-other) & On request patient-Other-No opinion) \\
& Did you receive information from the GP \\
& that significantiy influenced your policy \\
& with this patient? \\
& (Multiple answers allowed: Yes, social data- \\
& Yes, from history-Yes, from investigations- \\
& Yes, other-No-No opinion) \\
In your opinion, could the GP have resolved & this case independently? \\
(4 point Scale: Yes-No-Other-No opinion)
\end{tabular}

The medical ethical committee of the University Hospital had approved the study.

\section{Results}

During the 2 years of the study, $166(87.8 \%)$ of 189 eligible patients were included. Twenty-three patients were referred to the outpatient clinic of rheumatology by the participating GPs without entering the study. Declining to participate (16/23) and the GPs opinion that a patient was not suitable for Joint Consultation $(4 / 23 ; 3 / 23$ other reasons), was the main reason for nonparticipation (mean age 51.2 years (SD: 17.8 ); 30.4\% male). This non-participation was equally spread over the study period. The mean age of the participating patients was 53.7 years $(S D=14.0) ; 27 \%$ was male.

Figure 1 shows the degree in which patients take their complaint(s) seriously and their concern about the complaint(s) as recorded by questionnaires. When the GPS indicate, to their opinion if the patient believes their complaints to be serious or if the patient is concerned about the complaint, they often do not perceive the same level of seriousness and do not indicate the same level of 
concern as patients. In other words, patients often do not get their worries across.

Figure 1: The answers to the question for the patient: "How serious do you think your complaint is" and "How worried are you about the complaint". The level of agreement with the GP is also shown.

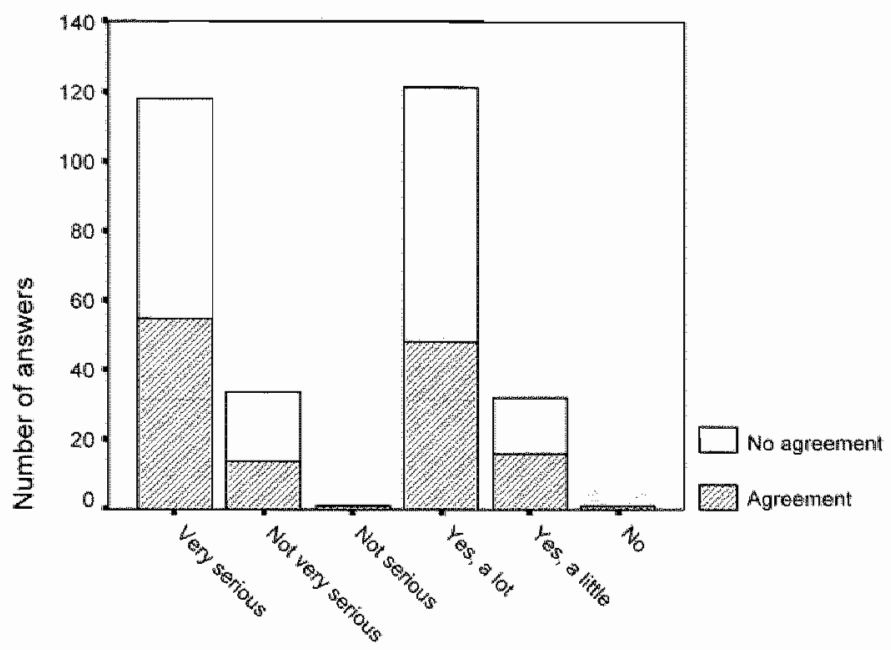

This discrepancy between GPs and patients is explored in detail. Patient expectations towards the consultation were recorded as well as patient expectations as perceived by the GP. The overall agreement between what patients expected from the consultation of the GP and the perception of GPS on the patient expectations was $39.3 \%(67 / 172$ (more answers were allowed)).

Nonetheless, patients predominantly felt they had received enough attention (75.5\% of the cases $(120 / 159))$ and enough explanation by the $\mathbb{G P}(62.3 \%$ of the cases (99/159)) (as indicated specifically in the questionnaires). The level of reassurance by the GP, however, was low $(42.8 \%(68 / 159)$ of the patient indicated not be reassured at all). After Joint Consultation or consultation to the outpatient clinic rheumatology, the level of reassurance was significantly higher (13.4\% (20/149) of the patients indicated not to be reassured; p<0.001, ChiSquare). No difference in the level of reassurance resulting from Joint Consultation or the outpatient clinic was noted.

Aspects of communication between GPs and rheumatologists are provided in Figure 2 , showing the reasons for referral as indicated by the GP and the reasons for referral as perceived by the rheumatologist. 
Figure 2: Reasons for referral by GPs as indicated by the GPs and perceived by rheunatologists.

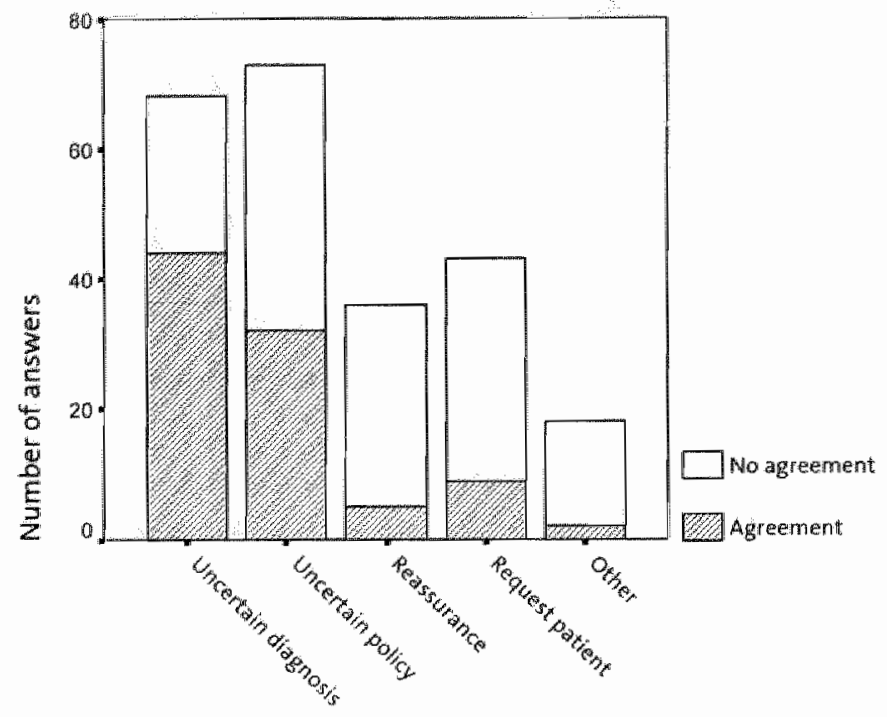

Uncertainty about diagnosis and therapeutic policy are predominantly the reasons for referral. Note that the reasons for referral as perceived by rheumatologists differ from the reasons indicated by GPs; especially for the categories reassurance and request patient. The overall agreement on the reasons of referral was $38.7 \%(92 / 238$ (more answers were allowed)). There was no difference between control and intervention group cases (patients examined at the outpatient clinic and patients examined in Joint Consultation). Rheumatologists indicated in the questionnaires whether or not they had received information from the GP that considerably influenced their policy. For referrals to the outpatient clinic, rheumatologists said to have received influential information in $14.5 \%(10 / 69)$ of the cases, whereas the rheumatologist indicated to have received such information in $57.3 \%(47 / 82)$ of the cases in Joint Consultation (Table 2). This statistically significant difference ( $p<0.001$; Chi-Square) is categorised for the type of information rheumatologists claimed influenced their policy. Especially social data are indicated to be more often influential in the policy for the patients examined in a Joint Consultation $(30.3 \%(20 / 66)$ vs. $7.7 \%(1 / 13)$ for outpatient clinic patients). Patient history influenced policy most often for both intervention as well as control group patients.

Finally, the opinion of the rheumatologist regarding whether or not GPs should have treated the patient independently of specialised care, differs 
significantly between Joint Consultation and outpatient clinic. In 42.7\% (35/82) of the Joint Consultation patients, rheumatologists indicated that the GP should have treated the patient independently, versus $95.7 \%(66 / 69)$ of the patients they examined at the outpatient clinic (thereby indicating the patients were not rightfully referred). ( $p<0.001$; Chi-Square)

\section{Discussion}

In our study, we found considerable differences in the patient-doctor communication, as well as in the communication among doctors.

As for the communication between GPS and patients, the difference in perception on how seriously complaints are taken by the patient plus the level of concern was considerable. The difference in perception is also demonstrated in the specific expectations the patient had towards the consultation and the expectations the GP thought the patient had. Basically, this shows that patients and doctors often have different angles to the same problem. A non-fatal disease may not trouble the GP, but can worry the patient nevertheless considerably. In other words, what a patient may consider a serious complaint, GPs (from a medical perspective) may perceive harmless. This medical perception of the complaint could "blind" the GP to the worries of the patient. So, this discrepancy is important since it may contribute to medical consumption. As we have shown, most patients felt that they received adequate attention and explanation. On the other hand, many patients also indicated that they were not reassured. Since all patients entered the study because they could not be treated only by CPs (and had to be referred), a lack of reassurance may be logical. However, patients who are not reassured may demand more consultations, more diagnostic tests, referral and so on. First of all, this suggests that it is important for doctors to assess and understand what a complaint or clinical problem means to the individual patient. Without any doubt, this will influence the management of the problem. We have shown here that Joint Consultation could positively influence this, since a consultation with the specialist might be all the reassurance a patient needs, as demonstrated by the increase in reassurance after a consultation at either a Joint Consultation or a consultation at the rheumatology outpatient clinic. In the meantime GPs learn how to diagnose and treat specific clinical conditions for future patients, without referral.

As for the communication between GPs and rheumatologists, the reason for referral as indicated by the GP differs from the reason perceived by the rheumatologist. Especially the categories reassurance and request patient show little agreement. The personal collaboration in Joint Consultation does not seem 
to improve the perception of the rheumatologist on the reason of the GP to refer. Perhaps CPS rather indicate "medical" reasons such as uncertainty diagnosis and policy than admit to needing a referral for reassurance or on the patient's request.

Rheumatologists indicated to have received substantially more infiuential information on the patient from the GP than in regular referrals, suggesting that the communication between GPS and specialists in Joint Consultations renders more data, which can be used in the treatment of the patient. Furthermore, rheumatologists indicated in Joint Consultation that the majority of the patients presented could not have been treated by the GP independently, making it an appropriate referral. Only few cases at the outpatient clinic were assessed as such. This may suggest that the communication during Joint Consultation leads to a better appreciation of referrals by specialists. The referral letter (which as principal source of information to the specialist mainly focuses on patient history) does not seem to fully achieve an understanding by rheumatologists on why the patient could not have been treated by the GP independently of specialised care.

In short, although rheumatologists do not get a better insight into the reasons of GPS for referral, rheumatologists do get more data from the GP about the patients which influences their policy and they appreciate referrals in a larger extent in Joint Consultation.

We strongly believe that a model such as Joint Consultation enhances the primary care process at many levels. Although Joint Consultation may not be feasible in every health care system, shared care and disease-management models are widespread. More and more examples accur where patients are treated by different health care providers rather than isolated care form one professional. In these shared care or disease-management projects different health care providers are brought together with the intention of improving patient care. Obviously, inter-professional communication is an important aspect, if not prerequisite for these forms of collaboration.

The study on Joint Consultation shows that these health care providers also improve in communication when working together. Secondly, Joint Consultation reassures patients in the same degree as the outpatient clinic without actual referral. This could be of great influence to patient satisfaction and consequently to medical consumption.

Joint Consultation therefore provides a collaboration model that educates doctors, improves referral and diagnostic behaviour, and improves communication. 


\section{References}

1. Bell RA, Kravitz RL, Thom D, Krupat E, Azari R. Unsaid but not forgotten: patients" unwoiced desires in office visits. Arch Intern Med 2001;161:1977-84.

2. Doeleman F. Improving communication between general practitioners and specialists. Fam Pract $1987 ; 4: 176-82$.

3. Levenstein $\mathrm{HH}$, McCracken EC, MCWhinmey IR, Stewart MA, Brown JB. The patient-centred clinical method. 1. A model for the doctor-patient interaction in family medicine. Fam Pract 1986;3:2430 .

4. Westerman RF, Hull FM, Bezemer PD, Gort G. A study of communication between general practitioners and specialists. Br J Gen Pract 1990;40:445-9.

5. Rao JK, Weinberger $M$, Kroenke K. Visit-specific expectations and patient-centered outcomes: a literature review. Arch Fam Med 2000;9:1148-55.

6. Grundmijer. General practitioner and specialist: why do they communicate so badly? European Journal of General Practice 1996:2:53-54.

7. de Melker $R$. It takes two to tango. Huisarts en Wetenschap 2001:44:258 259 .

8. Schulpen GJC, Vierhout WPM, van der Heijde DM, Landewe RB. Winkens RAG, WesselinghMegens AMK, et all Joint Consultation of General Practitioner and Rheumatologist: Does th matter? Ann. Rheum. Dis. 2003; 62:159-61.

9. Vierhout WPM, Knottnerus JA, van Ooij A, Crebolder MFIM, Pop P, Wesselingh-Megens AMK, et al. Effectiveness of joint consultation sessions of general practitioners and orthopaedic surgeons for lacomotor-system disorders. Lancet 1995;346:990-4. 



\section{Chapter 5}

\section{Patients at the outpatient rheumatology clinic}

\section{Do they really need to be there?}

GJC Schulpen, WPM Vierhout, DM van der Heijde, RB Landewé, RAG Winkens, AMK Wesselingh-Megens, 5 van der Linden

European Journal of Internal Medicine; Accepted. 


\section{Abstract}

Background: The workload at many outpatient clinics within the Dutch health care system has been growing relentlessly, resulting in unacceptable waiting lists and reduced accessibility. Assessing streams of patients and introducing a method of accelerated referral of patients back to the general practitioner (GP) under specialist guidance could help to alleviate these problems.

Methods: Seventeen GPs collaborated with rheumatologists during a 2-year period in a "Joint Consultation" model in which GPS and rheumatologists discussed patients together. All patient charts belonging to patients who had been referred to the outpatient clinic by these 17 GPS were identified. Rheumatologists assessed whether or not these patients could be referred back to the participating GPs under the guidance of the specialist in the Joint Consultation model.

Results: Of 276 eligible patients, 121 were discharged from the outpatient clinic. Eighty-seven patients required specialist follow-up, 22 patients refused to participate, and 6 patients were not entered into the study by the rheumatologist. Some 21 patients eventually entered the study, 18 of whom were referred back to the GP.

Conclusion: The role of Joint Consultation appears to be limited. Improving the referral behaviour of GPS should take precedence over transferring follow-up from the outpatient clinic to the primary care level. 


\section{Introduction}

Over the last decade, the University Hospital of Maastricht has studied the effects of Joint Consultation (1-4). This model constitutes collaboration between general practitioners (CPS) and specialists with the aim of educating and improving health care. On a six-weekly basis, each specialist visited the practice of a hosting GP who, together with two colleagues, presented patients whom they wanted to refer or whom they wanted to consult the specialist for. This close collaboration has been shown to have a strong educational effect on the participating GPs (2-4). We have demonstrated in the fields of orthopaedic surgery, cardiology, and rheumatology that Joint Consultation can eventually lead to, among other things, a decrease in the referral rate of participating GPS, a decrease in the use of diagnostic tools, and to satisfaction of the patients (1-4).

One of the criticisms of Joint Consultation, however, has been the lack of focus on secondary health care. Joint Consultation is aimed at improving the diagnostic and therapeutic competence of GPs. The GP has, thus far, been the one to present patients in a Joint Consultation session.

The proposal made in the present study was to have the specialist also present a part of his patient population to the GP in a Joint Consultation session. The hypothesis was that of all patients at the outpatient clinic, there would be one group that absolutely required specialist follow-up, another group that would be discharged without needing any additional medical follow-up, and yet a third group that would require medical follow-up, but not necessarily by a specialist; these patients could also be monitored by a skilled GP. The specialist would also be able to introduce patients from the outpatient clinic in the Joint Consultation session and transfer follow-up to the GP. Consequently, the outpatient clinic, with its long waiting lists, would be relieved of the workload of a number of patients, improving accessibility.

In this paper it is this last aspect - referring patients back to the GP through Joint Consultation - that we have tested within the framework of the Joint Consultation between GPs and rheumatologists.

\section{Methods}

Seventeen GPs in the vicinity of the University Hospital of Maastricht participated in this 2-year (1999-2000) study. In a questionnaire distributed to all GPs in the area $(N=90), 66 \%$ indicated their willingness to participate in "Joint Consultation" with a rheumatologist. Refusal to participate was predominantly based on a perceived lack of time. The final selection of participants was based on the availability of GPS for this study and on criteria matching the participants to 
the general population of GPS. The latter included practice characteristics (solo, group practice) and location (urban, rural), as well as referral behaviour to the outpatient rheumatology clinic (10-12 referrals/GP per year). Seventeen GPs were finally selected. All six staff members of the Department of Rheumatology were assigned as consultants.

A Joint Consultation session took place once every 6 weeks and included a fixed group of three GPs and one visiting rheumatologist at the practice of a host GP. During each session GPS would first present their patients (newly referred patients); the consulting rheumatologist would then re-examine each of them and formulate a diagnostic and therapeutic policy for him or her, together with the GP. At the same time, the consulting rheumatologist was given the opportunity to present patients from the outpatient clinic.

In October 1998 (just prior to the start of the study), the medical administration of the University Hospital of Maastricht provided a list of all patients seen at the outpatient rheumatology clinic who had been referred by the 17 participating GP5. All patient charts of this selected group were specially marked, and a questionnaire was added to each patient's file to be completed by the rheumatologist at a later date. During the 2-year study period, whenever the rheumatologist was given such a marked chart, he was asked to assess whether or not that patient could be referred back to his/her GP. If, in the opinion of the rheumatologist, the patient still required specialist care at the outpatient clinic, he had to provide reasons for it (in writing). When patients were considered eligible for referral back to their GP, they entered the study after providing informed consent.

Patients were randomised into two groups: those who remained under the specialists' care at the outpatient clinic (control group) and those who were referred back to the GP (intervention group). Patients who were eligible for referral back to the GP were presented by the consulting rheumatologist to the CP who had originally referred them to the outpatient clinic. Then, in the presence of the patient, the rheumatologist explained how the GP should proceed in his/her follow-up of that particular patient. From that moment on, the medical care for this patient was fully transferred back to the GP. If at any time during the follow-up, the CP was confronted with a rheumatological problem involving that patient, he had the opportunity to consult the rheumatologist about it during the next Joint Consultation session.

All patients were followed up for one year after entering the study, which was approved by the medical ethics committee of the University Hospital. 


\section{Results}

At the start of the study, 276 patient charts were identified as belonging to patients who, at some point in time, had been referred to the outpatient rheumatology clinic by the 17 participating GPs (Figure 1). The mean age of the selected group was 59.1 years (SD: 15.4$)$ and $30.8 \%$ of the group was male. Of the questionnaires that had been added to the charts of these 276 patients, 120 were returned by the rheumatologists. Patients for whom a questionnaire was not returned $(\mathrm{N}=156)$ included 121 who had already been discharged from the outpatient clinic, 23 who were reported by the rheumatologist to have active illness requiring specialist follow-up, and 1 who had died. Data were not available for 11 patients (Figure 1).

Of the 120 patients for whom questionnaires were returned, 27 were considered eligible for referral back to their GP. Twenty-one of these patients were included in the study. Of these 21 patients, 18 were referred back to the GP after randomisation and, in a Joint Consultation, the rheumatologist transferred the medical follow-up back to the GP. The randomisation was allocated per rheumatologist and the $17 \mathrm{GPs}$, resulting in too many strata. This, in turn, resulted by chance in the allocation of more than the expected $50 \%$ of the 21 patients in the intervention group.

The other six patients who were eligible for referral back to their GP were never entered into the study by the rheumatologist who had made the assessment. Three of them were subsequently discharged from the outpatient clinic.

All patients were followed up for 1 year. Ten of the patients referred back to their GP received the usual follow-up. Eight other patients, however, returned to the outpatient rheumatology clinic during the year of follow-up, one due to increased complaints, one on the request of a neurologist, and six for no specified reason.

The majority $(\mathrm{N}=93)$ of the patients who were assessed by rheumatologists were considered ineligible for referral back to the GP. Several reasons were given, such as refusal by the patient to be re-referred $(N=22)$, active illness requiring specialist follow-up ( $N=52)$, non-active illness that still required specialist followup $(N=12)$, and discharge from the outpatient clinic $(N=2)$. In five patients data were not available. Patient charts were examined for those patients whom the rheumatologist claimed required specialist follow-up, revealing obvious signs of active disease in the majority of cases. Active disease was established on the basis of determinants that could be retrieved from the patients' charts without the need for discussion regarding interpretation, i.e., constant or recurrent elevation of ESR and/or radiological progression or non-responsiveness to drugs, 
as indicated specifically by the rheumatologist in writing to the GP. In $75 \%$ of the cases; active disease was classified by these standards.

Figure 1: Flowchart of all patients of the 17 GPs (participating in the Joint Consultation model) who were dentifled at the outpatient rheumatology clinic.

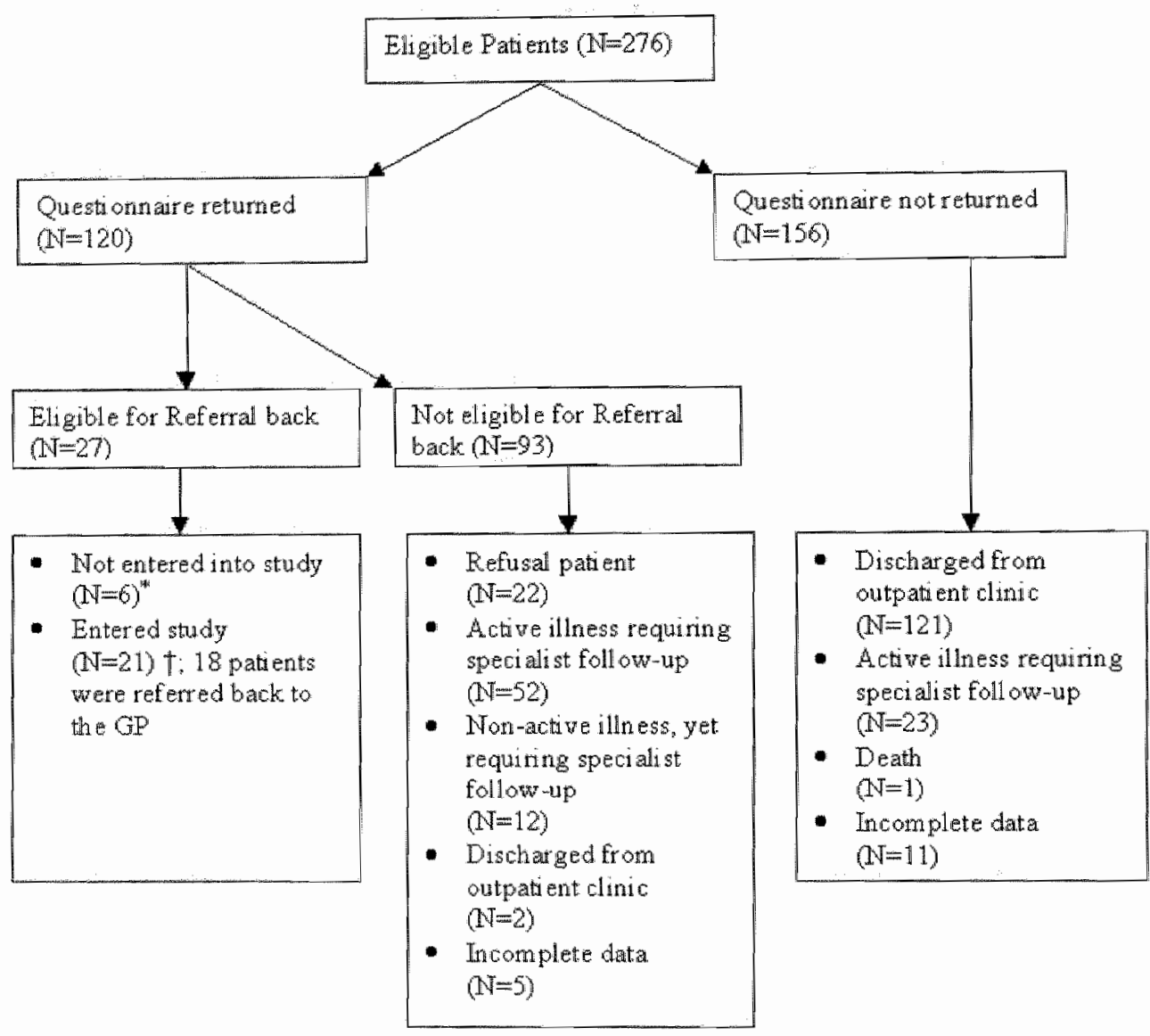

" reasons not specified: 3 patients were subsequently discharged from outpatient clinic.

1: 10 patients got successful follow-up from GP: 11 patients reappeared at the outpatient dinic (due to increased complaints $(N=1)$, due to request nemrologist $(N=1)$, due to randomisation into control group $(N=3)$ and no reason specified $(N=6))$. 


\section{Discussion}

The additional value of Joint Consultation as a form of education and collaboration between general practitioners and specialists has been demonstrated for several fields of medicine. This is important in Dutch health care since long waiting lists exist, especially for the outpatient rheumatology cllinic. Moreover, reshuffling patient flows (something that is facilitated by the educational effects of Joint Consultation) can lead to better disease management at all medical levels. In a recent study of Joint Consultation (5), rheumatologists transferred medical follow-up from the GP to the outpatient clinic in only $15 \%$ of the cases; in all other cases, the rheumatologists only performed a single consultation during Joint Consultation (5). Given the fact that the kinds of diagnoses made during Joint Consultation are evenly distributed/cover a wide range (from osteoarthritis to rheumatoid arthritis, and from fibromyalgia to arthralgias) (5), one may conclude that rheumatologists feel comfortable transferring follow-up of the majority of referrals (covering the entire range of rheumatological diagnoses) to the GPs.

It has repeatedly been suggested that Joint Consultation could also be an effective platform to transfer follow-up from the outpatient clinic to the GP. This hypothesis was tested in the present study on Joint Consultation and rheumatology. Of all the eligible patients $(N=276), 210$ had either already been discharged from the outpatient clinic or had, in the professional opinion of the rheumatologists, such a high degree of active disease that they still required follow-up by a specialist. in other words, for $76 \%$ of the eligible patients, there were good reasons not to be re-referred.

Nevertheless, $24 \%$ of the eligible patients could have taken part in the study. However, $8 \%$ refused to participate, and there was not enough available data for an additional $6 \%$. Twenty-one patients did enter the study (8\%), 18 of whom were referred back to the GP. Eight of them eventually reappeared at the outpatient clinic. One possible explanation for this could be that reappearing at the outpatient clinic and being seen by a specialist may seem to legitimise their medical condition more than returning to the care of a GP, at least in the mind of the patient. This attitude could represent a major obstacle to referral back to the $G P$, one that is difficult to influence. What's more, people are creatures of habit. Not only patients, but also doctors (GPs and rheumatologists) may be reluctant to change their routines. In other words, the $24 \%$ of eligible patients did not constitute a group of patients who could benefit from referral back to GPs through Joint Consultation. In fact, only 10 of the 276 eligible patients (4\%) benefited substantially from referral back to the GP. 
One could also argue that the patients who were said to require medical follow-up were wrongly classified as such. Perhaps the rheumatologists had little faith in the skills of the GP and readily chose to qualify patients as requiring a specialist. Yet, examination of the patient charts contradicts such a possible bias since most patients had clear evidence of active disease or other obvious reasons for specialist follow-up.

What, then, are the lessons to be learned from this study? The outpatient rheumatology clinic is still burdened with a large patient load. We feel that methods must be sought to reduce this load, methods such as patient triage, requesting the hellp of nurse practitioners, etc. Musculoskeletal conditions are common in primary care, and aiding GPS in diagnostic and therapeutic ways (through Joint Consultation) leads to a decrease in the patient population referred to the outpatient clinic. Yet, when assessing follow-up policy as a possible source for changing patient streams, the performance of rheumatologists seems satisfactory, and placing follow-up on the primary care level does not seem to be the solution to the problem. This is not meant to imply that follow-up at the outpatient rheumatology clinic cannot be approached from different angles. Perhaps the gap in specialist knowledge between rheumatologists and GPs is still too wide, despite Joint Consultation. A nurse practitioner could, for example, provide the skills needed to substitute a part of the follow-up load at a secondary health care level.

All in all, it seems that rheumatologists provide adequate follow-up policy; their behaviour does not need to be changed considerably. However, methods do need to be found that will help them reduce the burden of follow-up. 


\section{References}

1. Schulpen GIC, Vierhout WPM, van der Heijde DM, Landewe RB, Winkens $R A G$, WesselinghMegens $A M K$, et al. Joint Consultation of General Practitioner and Rheumatologist: Does it matter? Ann Rheum Dis; 2003:62:159-61.

2. Vierhout WPM, Knottnerus JA, van Ooij A, Crebolder HFJM, Pop P, Wesselingh-Megens AMK, et al. Effectiveness of joint consultation sessions of general practitioners and orthopaedic surgeons for locomotor-system disorders. Lancet 1995:346:990-4.

3. Vierhout WPM. Het Gezamenlijk Consult van huisarts en specialist in de eerste lijn. Amsterdam; Thesis Publishers; 1994.

Vlek JFM. Cardiologue, Joint consultation of general practitioners and cardiologists in a primary care setting. Maastricht: Datawyse; 2000.

4. Schulpen GJC, Vierhout WPM, van der Heijde DM, Landewe RB, van der Linden 5 , Winkens RAG. De waarde van een gezamenlijk consult wan huisartsen en reumatologen bij patiënten in de eerste lijn. Ned Tijdschr Geneeskd 2003;147:447-50. 



\section{Chapter 6}

\section{Joint consultation of general practitioners and rheumatologists}

Costeminimisation analysin of

GJC Schulpen, A Boonen, WPM Vierhout, JL Severens, DM van der Heijde, $S$ van der Linden

Submitted 


\section{Abstract}

Joint Consultation is a model of collaboration between general practitioners and rheumatologists which has the aim of improving efficiency of health care for patients with rheumatological complaints. In a randomised-controlled trial, the effects of Joint Consultation were assessed as it relates to feasibility, efficiency and costs.

The costs per patient were assessed for the outpatient clinic setting (integral costs: 313 euro's) and compared to the Joint Consultation setting (integral costs: 529 euro's; marginal costs: 236 euro's). When extrapolating the effects of Joint Consultation (decrease in referrals and in use of diagnostic tools) the integral costs for the outpatient clinic setting was 5388 euro's per GP over two years, compared to 5167 euro's integral costs per CP (marginal costs: 2130 euro's/GP/2 years) for Joint Consultation. In conclusion, the effects concerning efficiency of Joint Consultation make this model cost less than regular referral to the outpatient clinic. These results make Joint Consultation a successful model of collaboration. 


\section{Introduction}

Limited budgets and quality of care constitute often a dilemma in health care innovation projects. Joint Consultation is a model of collaboration between general practitioners (GPs) and specialists with the goal of improving health care. GPs had six-weekly meetings at the practice of a host-GP and presented patients they had wanted to refer to a visiting mheumatologist. Together with the specialist, the GPs formed a policy and learned this way what they could have done. This in turn educated the GPs to treat similar problems independently in the future.

Apart from the quality of health care and (logistical) feasibility, Joint Consultation demonstrated important other effects. One of the most striking secondary effects was that the participating GPs, after two years of Joint Consultation, referred $62 \%$ less patients than GPs that had not participated in the study (1).

The overall assessment of Joint Consultation was positive; GPs referred less, fewer follow-up consultations were needed, rheumatologists used less diagnostics in Joint Consultation than at the outpatient clinic, patients are reassured by Joint Consultation, patients are satisfied with Joint Consultation. While at the same time, health status of patients at the outpatient clinic (after one year) was comparable to health status of patients after Joint Consultation (after one year) (measured by Euroool-5D) (1-4).

However, to implement a positively evaluated model of health care in daily practice, one important factor has to be considered. Apart from efficacy, how expensive is this new way of health care compared to the existing situation?

In this paper we analyse costs of both the traditional way of referral by the GP to the outpatient clinic of rheumatology and the care of patients through Joint Consulltation.

\section{Methods}

During a period of 2 years (1999-2000), rheumatologists treated referred patients at either the outpatient clinic of rheumatology (usual care group) $(\mathrm{N}=79)$ or they treated patients together with the referring GP at the practice of the GP (intervention group) $(N=87)$. This educated the GPs and in turn resulted in a decrease in referrals of the participating GPs. So, the participating GPs referred 166 patients in total over a two year period, whereas they would have referred more (at least 292 patient based on their referral rate prior to the study) if they 
had not participated in this educational Joint Consultation model. A more detailed report on the clinical trial has been reported elsewhere (1-4).

\section{GP selection}

Responding to a questionnaire among all GPS $(N=93)$ in the region of the University Hospital Maastricht, The Netherlands, 60 (or $65 \%$ ) of the GPs said to be willing to participate in a Joint Consultation with a rheumatologist. Declining to participate was mostly based on a perceived lack of time. The final selection of participating GPs was based on availability for this study and criteria that would match the participants to the general population of referring GPs; 1) practice characteristics (solo, group-practice), and location (urban, countryside) and 2) referral behaviour (10-12 referrals to the dlepartment of rheumatology per GP per year). Seventeen GPs were selected and agreed to participate (mean age 48.5 years, $12 \%$ female, $47 \%$ rural practice; no significant differences in characteristics were observed comparing with non-participating GPs). Besides, referral pattern of the participating GPs matched the referral pattern of non-participating GPs. This overall referral pattern to the outpatient clinic of rheumatology was neither prior to the study nor during the study influenced by other interventions that could have influenced referral behaviour such as guidelines or educational programs. There were no reasons to assume that the competency of dealing with musculoskeletal problems of GPs in this region differs from that of other Dutch GPs. The 43 non-participants who expressed a willingness to participate acted as usual care group. The referral rates (and practice/personal characteristics) of non-participating GP5 who were willing to participate in the study $(N=43)$ were comparable to those of GPs who declined to participate ( $N=33)$.

\section{Rheumatologist selection}

All six staff-members of the department of rheumatology at the University Hospital Maastricht were assigned as consultant.

\section{Patient selection}

Any patient the participating GPs wanted to refer to the outpatient clinic of rheumatology, could be included into the study except for patients needing emergency referral. These patients were randomised for Joint Consultation of direct referral to the outpatient clinic.

\section{The economic evaluation}

The economic evaluation will be a cost minimisation analysis, which consists of two parts. The first part considered the costs based on the empirical data. In other words, the costs (per patient) resulting from the time invested by the 
doctors and the diagnostic tools used, at either foint Consultation or outpatient clinic.

The second part will describe the costs (per GP practice for the care of patients with a rheumatic complaint) based on the extrapolation of the results. This constitutes a theoretical comparison between the situation in which $17 \mathrm{GPs}$ s only refer to Joint Consultation during two years versus $17 \mathrm{GPs}$ only refer to the outpatient clinic during two years. In the latter situation, GPs would not benefit from the educational effects of Joint Consultation and they would presumably differ in referral behaviour from the first situation.

As is common in economic evaluation a cost analysis consists of two steps: analysing volumes of investment (time of doctors, number of outpatient clinic visits etc) and determination of the cost price for each volume. Multiplying volume by cost price results in a cost estimate. A health care perspective was used thus real costs in stead of tariffs were basis for the analysis. Besides this, the analysis aimed to study only the direct medical costs and did not include indirect costs, non-medical costs and patient out-of-pocket costs. All costs were calculated per patient and expressed as euro (1 US $\$=0.9989$ euro as of November 5 th 2002). All costs are calculated for the duration of two years (19992000) of the intervention. Data on costs were gathered using questionnaires after consultation.

Table 1: Unit cost data for the rheumatologists and GPS applied for either outpatient clinic or Joint Consultation setting.

\begin{tabular}{llll}
\hline & Outpatient clinic & Joint Consultation & \\
\hline & & Integral costs & Marginal costs \\
Rheumatologist & $245,46^{\text {s }}$ & $245,46^{*}$ & $108,18^{*}$ \\
$\begin{array}{l}\text { (euro/hour) } \\
\text { GP }\end{array}$ & $99,60^{1}$ & $99,60^{\mathrm{j}}$ & $99,60^{\circ}$ \\
(euro/hour) & & & \\
\hline
\end{tabular}

${ }^{2}$ including overhead

${ }^{2}$ excluding overhead

National directive for the integral costs of consultations by a rheumatologist was 245.46 euro's per hour (including overhead). The national directive for the hourly wage of rheumatologists was 108.18 euro's (exciuding overhead). The directive for the integral costs for consultations by GPS was 99.60 euro"s per hour (including overhead) (Table 1). 
The costs for both the empirical data and for the extrapolated data are presented as integral costs as well as marginal costs. The integral costs (market value of resources or services in its optimal use based on the principle of opportunity costs) are presented for a general overview of costs and marginal costs (the extra costs of one additional service) are presented because Joint Consultation constitutes new insights into costs; market value of resources may change when one changes the setting of that resource. The marginal costs are based on the assumption that during Joint Consultation:

a) rheumatologists can be employed for the sole purpose of Joint Consultation and therefore, overhead of the outpatient clinic is not of relevance

b) of the three GPs present during a Joint Consultation session, only one is referring the patient. The other two GPS are present for the purpose of education (and are rewarded with required educational accreditation accordingly) and need not to be included in the billing.

Sensitivity analysis will be presented for duration of follow-up consultations and for the degree of decrease in referral rate for the Joint Consultation data.

\section{Empirical part}

\section{Unit cost data}

Time invested by physicians and diagnostic tests were the components used for the unit cost. The time per patient for the outpatient clinic was not recorded as such, but every first consultation at the outpatient clinic is booked for 45 minutes and every follow-up consultation is booked for 15 minutes. The prices

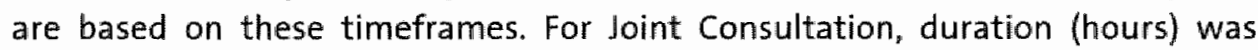
recorded through questionnaires for each patient.

\section{Diagnostics}

All diagnostic requests were recorded at either outpatient clinic or Joint Consultation. The prices for diagnostics are based on the direct costs, which were supplied by the University Hospital Maastricht. All GPs as well as all rheumatologists used the diagnostic department of the University Hospital Maastricht for diagnostic requests.

The medical ethical committee of the University Hospital Maastricht had approved the study. 


\section{Extrapolation part}

These data are extrapolated from the effects that Joint Consultation has on referral rates of GPs and on diagnostic requests by rheumatologists. These data illustrate the situation if all $17 \mathrm{GPS}$ had referred to the outpatient clinic only or if all $17 \mathrm{GPs}$ had referred to Joint Consultation sessions only.

\section{Unit cost data}

Time invested by physicians and diagnostic tools were the components used for the unit cost. The time per patient for the outpatient clinic was not recorded as such, but every first consultation at the outpatient clinic is booked for 45 minutes and every follow-up consultation is booked for 15 minutes. The prices are based on these timeframes.

\section{Diagnostics}

All diagnostic requests were recorded at either outpatient clinic or Joint Consultation. The prices for diagnostics are based on the direct costs, which were supplied by the University Hospital Maastricht. All GPs as well as all rheumatologist use the diagnostic department of the University Hospital Maastricht for diagnostic requests.

Because during the experimental Joint Consultation sessions more than one patient is discussed, it is impossible to determine the cost per patient straightforward. Thus, total cost for both strategies were determined and subsequently divided by the number of patients treated by this strategy to result in an estimate of the cost per patient.

\section{Results}

During the 2 years of the study, a total of 166 patients were included by the 17 participating GPs. Twenty-three patients were referred to the outpatient clinic of rheumatology without entering the study. Declining to participate from the part of the patient $(16 / 23)$ and the GPs opinion that a patient was not suitable for Joint Consultation $(4 / 23 ; 3 / 23$ other reasons), was the main reason for nonparticipation. This non-participation was equally spread over the study period ( 24 months). Table 2 shows the patient characteristics. 
Table 2: Patienit characteristics.

\begin{tabular}{lll} 
& Characteristics participants & $\begin{array}{l}\text { Characteristics non- } \\
\text { participants }\end{array}$ \\
\hline Number & $N=166$ & $N=23$ \\
Age & 53.7 years (SD: 14.0) & 51.2 years $(50: 17.8)$ \\
Sex & $27.1 \%$ male & $30.4 \%$ male \\
\hline
\end{tabular}

\section{Empirical data (on patient level)}

\section{Costs outpatient clinic}

The sum of patients consulting the outpatient clinic was 79 , resulting in 59.25 hours first consultation time (Table 3). Follow-up consultations amounted 96 , resulting in 24 hours of consulting time. Rheumatologists spent in total 83.25 hours of consulting time at a rate of 245,46 euro's per hour. Table 4 shows that this in turn leads to 258,67 euro's per patient.

Table 3: This tables shows the volumes of resources (time of doctors, number of outpatient clinic visits etcetera).

\begin{tabular}{|c|c|c|}
\hline & Outpatient clinic & Joint Consultation \\
\hline Sum of patients & 79 & 87 \\
\hline Number of consultations & 79 first $^{1}$ & 8.7 first $^{2}$ \\
\hline & 96 follow-up & 47 follow-up \\
\hline Physicians present & 1 rheumatologist & $\begin{array}{l}1 \text { rheumatologist } \\
3 \text { GPS }\end{array}$ \\
\hline $\begin{array}{l}\text { Diagnostic tools used } \\
\text { (sum of all request) }\end{array}$ & 456 & 118 \\
\hline
\end{tabular}

"with a pre-set duration of 45 minutes per patient

2 with an average duration of 52 minutes (min 43-max 80 minutes) per patient

${ }^{3}$ with a pre-set duration of 15 minutes per patient

"resulting from patients referred to the outpatient clinic and with a pre-set duration of 15 minutes per patient. 
Table 4: This table shows the costs per patient over the two year intervention period for the distinguished categories of costs. The costs of Joint Consultation were calculated using integral and marginal approach.

\begin{tabular}{llll}
$\begin{array}{l}\text { Costs per patient } \\
\text { (euro) }\end{array}$ & Outpatient clinic & Joint Consultation & \\
\hline & & Marginal \\
Rheumatologist & 258,67 & 213,30 & 94,00 \\
GPs & - & 259,65 & 86,55 \\
Diagnostics & 54,94 & 22,94 & 22,94 \\
& & & 236,65
\end{tabular}

Diagnostics

The direct costs of the diagnostic requests for the outpatient clinic group led to a total sum of 4340,31 euro's (54,94 euro's per usual care group patient) (Tables 3 and 4).

Total

The integral costs per patient for the outpatient clinic group was 313,61 euro's.

\section{Costs Joint Consultation}

The costs for the Joint Consultation consultations are calculated in two ways (Tables 3 and 4).

\section{Integral costs of Joint Consultation}

The sum of patients consulting the rheumatologist through a Joint Consultation session was 87 . Eighty-seven patients required 75.6 hours of Joint Consultation (average 52 minutes; minimum 43-maximum 80 minutes). Integral costs for the rheumatologist amounted 75.6 hours ${ }^{*} 245,46$ euro/hour is 18556,78 euro"s. Integral costs for the (three) GPS is 3 * 75.6 hours * 99,60 euro/hour is 22589,28 euro's. However, this only relates to the patients who were treated in a Joint Consultation session; some of them were subsequently referred to the outpatient clinic. Of those patients referred to the outpatient clinic of rheumatology, the sum of consultations at the outpatient clinic was 47 (for a standard duration of 15 minutes). These outpatient clinic consultations took up 11.75 hours of rheumatologists' time, at a rate of 245,46 euro's per hour, leading to a total of 2884,16 euro's additional to the Joint Consultation costs.

The integral costs per patient is therefore $(18556,78+22589,28+2884,16) /$ 87 patients is 506,09 euro's. 
The direct costs of the diagnostic requests for the Joint Consultation group led to a total sum of 1995,44 euro"s $(22,94$ euro's per usual care group patient). The total costs per patient for Joint Consultation is 529,03 euro's.

\section{Marginal costs of Joint Consultation}

The number of patients in Joint Consultation is 87 and required 75.6 hours of consulting time during Joint Consultation. The costs for the rheumatologist during Joint Consultation are 108,18 euro's per hour leading to a sum of 8178,41 eura's. The costs for only the referring GP is 75.6 hours times 99.60 euro's per hour is 7529.76 .

The costs for those patients referred to the outpatient clinic remained the same (2884,16 euro's) as well as the diagnostic costs.

The marginal costs for Joint Consultation are $(8178,41+7529,76+2884,16) / 87$ is 213,70 euro's per patient plus the diagnostic costs of 22,94 euro's per patient leads to a total of 236,65 euro's per patient. 


\section{Extrapolated data (on GP level)}

The costs per patient are the same as presented before. However, when extrapolating the data, the amount of patients requiring either a referral to the outpatient clinic or to Joint Consultation sessions differs. This is best illustrated when expressing the costs as a total per GP for the duration of two years referring rheumatological patients.

\section{Outpatient clinic}

If the 17 participating GPs had referred all their patients to the outpatient clinic (and they could not benefit from the educational effects of Joint Consultation), based on their referral rates prior to the study (1), the GPs would have referred 292 patients (Table 5).

Table 5: Extrapolated data. This tables shows the volumes of resources (time of doctors, number of outpatient clinic visits etcetera).

\begin{tabular}{lll}
\hline & Outpatient clinic & Joint Consultation \\
\hline Sum of patients & 292 & 166 \\
Number of consultations & 292 first $^{1}$ & \\
& 355 follow-up $^{3}$ & 166 first $^{2}$ \\
& & 90 follow-up $^{4}$ \\
Physicians present & 1 rheumatollogist & 1 rheumatologist \\
& & 3 GPs \\
Diagnostic tools used & 1685 & 225 \\
(sum of all request) & & \\
\hline
\end{tabular}

${ }^{1}$ with a pre-set duration of 45 minutes per patient

${ }^{2}$ with an average duration of 52 minutes (min 43 - max 80 minutes) per patient:

${ }^{3}$ with a pre-set duration of 15 minutes per patient

"resulting from patients referred to the outpatient clinic and with a pre-set duration of 15 mimutes per patient 
These 292 patients would require 292 first consultations with a standard duration of 45 minutes (219.0 hours) and 355 follow-up consultations with a standard length of 15 mimutes ( 88.8 hours).

The integral costs for the rheumatologists would be (219.0 hours +88.8 hours) * 245.46 euro's per hour is 75552.59 euro's. Costs of diagnostic tools: 292 patients* 54,94 euro/patient is 16042,48 euro's.

Sum: 91595,07 euro's, resulting in 5387,95 euro's per participating GP over a period of two years of referrals to the outpatient clinic of rheumatology (Table 6).

Table 6: This table shows the average costs per GP over two years for the distinguished categories of costs.

\begin{tabular}{llll}
\hline $\begin{array}{l}\text { Costsper GP } \\
\text { (euro) }\end{array}$ & Dutpatient clinic & Joint Consultation & \\
\hline \multirow{2}{*}{$\begin{array}{lll}\text { Rheumatologist } \\
\text { GPs }\end{array}$} & 4444,27 & Integral & Marginal \\
Diagnostics & - & 2407,67 & 1061,12 \\
& 943,68 & 2535,41 & 845,14 \\
Sum & & 224,00 & 224,00 \\
& 5387,95 & & 2130,26
\end{tabular}

\section{Joint Consultation}

If the 17 participating GPs had referred all their patients (thereby learning from the rheumatologist and gradually referring less; see methods) ( $N=166)$ to Joint Consultation sessions, $(166 / 87)^{*} 75.6$ hours is 144.25 hours would be spent on Joint Consultation and $(166 / 87)^{*} 47$ consultations of 15 minutes is 22.5 hours of follow-up (Tables 5 and 6 ).

\section{Integral costs}

GP: 144.25 hours $^{*} 3$ (GPs) ${ }^{*} 99,60$ euro/hour is 43101,90 euro's

Rheumatologist: 166.75 hours 245,46 euro/hour is 40930,46 euro's

Diagnostic tools: 166 (patients)"22,94 euro/patient is 3808,04 euro's

Sum: 87840,40 euro's, resulting in 5167,08 euro's per participating GP over a period of two years of Joint Consultation.

If we consider the same amount of patients and the same time frames, the marginal costs would be calculated as follows.

2. Marginal costs

GP: 144.25 hours ${ }^{*} 1(G P)^{*} 99,60$ euro/hour is 14367,30 euro's

Rheumatologist: $166.75^{*} 108,18$ euro/hour is 18039,02 euro's

Diagnostic tools: 3808,04 euro's 
Sum: 36214,36 euro's, resulting in 2130,26 euro's per participating GP over a period of two years of Joint Consultation.

\section{Sensitivity analysis}

In the above-mentioned calculations, only time of doctors and diagnostic tools are taken into consideration. We considered the use of medication, physiotherapy, medical aids and so on, in both usual care group and in the intervention group. No statistical differences were found. This implies that these compartments have no effect on cost differences between the outpatient clinic and Joint Consultation.

In the empirical data, if patients were referred to the outpatient clinic following a Joint Consultation session, we considered this consultation at the outpatient clinic a follow-up consultation. This follow-up consultation has a standard duration of 15 minutes.

If we take a standard duration of 30 minutes instead of 15 (since it is not always possible to have the follow-up consultation with the same doctor than in the Joint Consultation session. This would require more time) costs would barely change. The integral costs would increase by only 7,05 euro's to 536,08 euro's per patient and the marginal costs would increase by only 7,05 euro's to 243,70 euro's per patient.

\section{Figure 1}

This figure shows the trends in costs for Joint Cansultation (integral and marginal) versus the costs of the outpatient clinic for varying degrees of decrease in referral rate. The costs are expressed per GP.

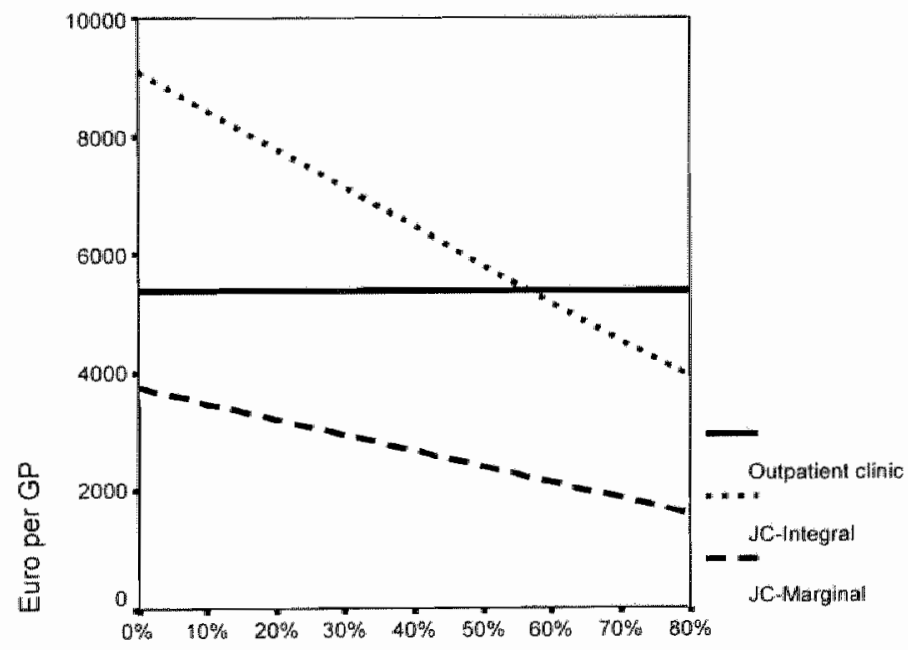

Decrease in referral 
In the extrapolated data, we take the decrease in referral rate (the learning effect of the GPS) into consideration. This effect may vary in other circumstances. Figure 1 shows the effects on the integral and marginal costs if the learning effect varies. At $0 \%$ the GPs remain unchanged in their referral rates and Joint Consultation is far more expensive than the outpatient clinic from a integral cost point of view. The figure shows that a decrease of referral of about $60 \%$ has to be achieved in order to break even in integral costs when compared to the outpatient clinic. Marginal costs are less expensive at any referral rate. 


\section{Discussion}

Joint Consultation constitutes a collaboration model that holds educational effects, safeguards health status, increases communication and is favourable in terms of costs to the regular care.

A model like Joint Consultation is difficult to label in terms of costs. The presence of three GPs and a rheumatologist outside of the hospital is not a common situation. Common cost calculation as we have presented in the opportunistic costs are therefore not reflecting daily practice.

We have now implemented the Joint Consultation model for 80 GPS and 25 specialists and that helped to formulate the marginal cost calculation (11). Another factor which makes interpretation difficult is the steadily decreasing referrai rate of the participating GPs.

Despite the fact that innovative collaboration models such as Joint Consultation are difficult to assess in terms of costs, it is of vital importance to make that assessment nevertheless. In order to implement innovation, that seems to have sufficient beneficial effects, in daily practice, cost considerations are imperative to convince not only participants (GPs, specialists), but also policy makers (health care insurance, government).

We already have shown the positive effects on referral rates, therapeutic and diagnostic behaviour, communication and satisfaction (1-7). However, cost evaluation is even more important in a model as Joint Consultation, because Joint Consultation can be deceptive at first appearance. A specialist leaving the hospital to consult GPs for a relatively small amount of patients could very well lead to better quality of health care, but surely takes up far too much time to ever be cost-effective. This is often the first impression of Joint Consultation or similar models. The empirical data show that costs of the outpatient clinic are lower compared to the integral costs of Joint Consultation, and higher than the marginal costs of Joint Consultation.

Yet, we have demonstrated that when calculating the costs per GP over a 2 year period and taking into account 1) the derrease in referral rates, 2) the decrease in follow-up consultations after Joint Consultation as compared to the outpatient clinic, and 3) the lesser amount of diagnostic requests in Joint Consultation as compared to the outpatient clinic, the Joint Consultation strategy is less expensive than the treatment strategy based on regular referrals to the outpatient clinic. Comparing integral costs to costs of outpatient clinic, a decrease of $4 \%$ was observed in favour of Joint Consultation and a decrease of $60 \%$ was observed in favour of Joint Consultation for the marginal cost calculation. The latter figure reflects the maximum cost-saving from the Joint 
Consultation strategy. Two notes have to be made. First, we have not been able to take into consideration that those patients who are no longer referred by the GPs (learning effect) might consume more time of the GP. This might make our costs calculation somewhat less favourable. A second remark is the fact that the decrease in referral as we obsenved, is decrease that grows over time. It takes at least a year of Joint Consultations to achieve a learning effect resulting in $62 \%$ decrease in referral as we have found. This holds the consequence that this model needs investment in order to reduce costs. On the other hand, the learning effect will not stop after the two years of the study. Further study will have to indicate how long these learning effects remain.

There are no indications that the referral behaviour of the 17 participating GPS differed from the national referral behaviour for the field of rheumatology (at the start of the study). So if we extrapolate our findings to a national level, this would imply that with 16 million inhabitants in the Netherlands and 2500 people per average practice, referral to the outpatient clinic over 2 years would cost 34.5 million euro's and Joint Consultation (marginal costs) 21.7 million euro's. Joint Consultation would thus save 6.4 million euro's per year.

It goes without saying that all the effects of Joint Consultation would be irrelevant if the quality of the delivered care was compromised. Not only are the patients satisfied with the treatment in Joint Consultation, there are no indications that general health is compromised in comparison to the group of patients treated at the outpatient clinic.

All in all, Joint Consultation proves feasible from the point of view of costs in addition to prior proven efficiency. Although the here presented results are calculated based on the Dutch situation, Joint Consultation could very well be feasible (and efficient) in other health care systems. 


\section{References}

1. Schulpen CIC, Vierhout WPM, van der Heijde DM, Landewe RB, Winkens RAG, WesselinghMegens AMK, et al. Joint Consultation of General Practitioner and Rheumatologist: Does it matter? Ann Rheum Dis 2003; 62(2):159-61.

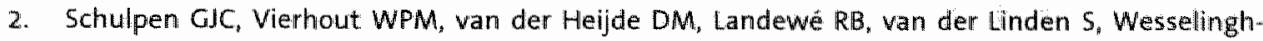
Megens AMK, et al. Patients, Family Physicians and Specialists: To communicate or not to comunicate? Submitted.

3. Schulpen GJC, Vierhout WPM, van der Heijde DM, Landewe RB, van der Linden 5 , Winkens RAG. De waarde van een gezamenlijk consult wan huisartsen en reumatologen bij patiënten in de eerste lijn. Ned Tijdschr Geneeskd 2003;147:447-50.

4. Schulpen GJC, Vierhout WPM, van der Heijde DM, Landewé RB, Winkens RAG, WesselinghMegens AMK, et al. Patients at the outpatient clinic of theumatology: Do they really need to be there? Eur J Intern Med In press.

5. Vierhout WPM. Het Gezamenlijk Consult van huisarts en specialist in de eerste lijn. Amsterdam: Thesis Publishers; 1994.

6. Vlek JFM. Cardiologue. Joint consultation of general practitioners and cardiologists in a primary care setting. Malastricht: Datawyse; 2000.

7. Vierhout WPM, Knottnerus JA, van Ooij A, Crebolder HFJM, Pop P, Wesselingh.Megens AMK, et al. Effectiveness of joint consultation sessions of general practitioners and orthopaedic surgeons for llocomotor-system disorder 5. Lancet 1995:346:990-4.

8. Essink Bot ML, Stouthard ME, Bonsel GI. Generalizability of valuations on health states collected with the EuroQolc-questionnaire. Health Econ 1993:2:237-46.

9. Hurst NP, Jobanputra $P$. Hunter $M$, Lambert $M$, Lochhead $A$, Brown $H$. Validity of Euroqol--a generic health status instrument--in patients with rheumatoid arthritis. Economic and Health Outcomes Research Group. Br I Rheumatol 1994;33:655-62.

10. Hurst NP, Kind $P$, Ruta $D$, Hunter $M$, Stubbings A. Measuring health-related quality of life in rheumatoid arthritis: validity, responsiveness and reliability of EuroQol (EQ-5D). Br J Rheumatol 1997:36:551-9.

11. Schulpen GJC, Vlek I, Vierhout WPM, Wesselingh-Megens AMK, Crebolder HFIM. Het win win consult. Transmurale samenwerking tussen huisartsen en specialisten. Medisch contact 2002;57:423-425. 

क्ये क्य

- क

a

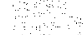

a 


\section{Chapter 7}

\section{The win-win consultation}

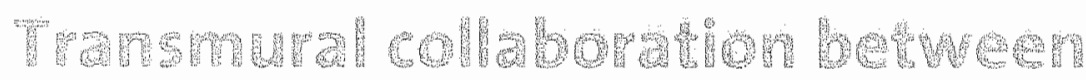

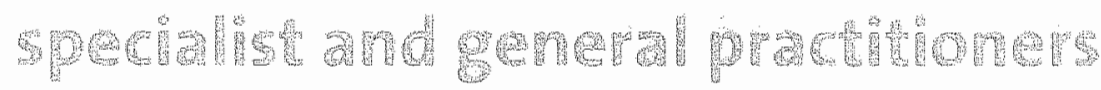

GIC Schulpen, JFM Vlek, WPM Vierhout, AMK Wessellingh-Megens, HFJM Crebolder.

Medisch Contact 2002;57:423-425. 


\section{Abstract}

Joint Consultations provide a possibility to improve collaboration between general practitioners (GPS) and speciallists.

Joint Consultation influences therapeutic and diagnostic behaviour, reduces referrals by GPS and is cost-effective.

Joint Consultation can obtain a place in regular health care through the "carrousel"-model with additional value for both GPs as specialists. 
Collaboration between general practitioners (GPS) and specialists needs to be improved. After all, the quality of care needs to be increased, communication between health care professionals needs to be improved and there is a need for advancement of expertise. Another reason is the accessibility of the health care system. The accessibility of secondary health care is increasingly compromised by waiting-lists problems. Changing patient-flows is dependant of the problemsolving capacity of both primary as secondary physicians. One way to increase the problem-solving capacity of GPs is to increase their skill and competence. A skilled, competent GP can treat more patients independently, refer more accurately, and thus influence the flow of patients to the outpatient clinic. The so-called "Joint Consultation" of GPs and specialist is a form of collaboration where the GP is taught using cases he himself provided. This method has proven to be an effective form of treatment as well as an effective form of education.

Toward the end of the eighties, Vierhout (of Maastricht University in collaboration with Transmural Diagnostic Centre Maastricht) carried out an investigation into the effects of Joint Consultation for orthopaedic surgery. Subsequently " similar studies have been performed on the field of cardiology (Vlek), dermatology (Bullens) and rheumatology (Schulpen)(1-6). These studies have been performed in order to test the model for several medical fields with different sorts of patients and with variations in the design of the model. This eventually resulted in the "carrousel"-model.

Although GPs and specialist collaborate increasingly in the Netherlands, Joint Consultation in this form is unique and as far as results and feasibility is concerned, remarkable.

\section{Host}

The organisation of the Joint Consultation is as follows. Participating GPS are divided into groups of three to four. Usually this is based on existing forms of collaboration. One of the GPS acts as host in his own practice. The groups gather on a monthly basis together with a consulting specialist. The GP can present patients that he had wanted to refer during that month or patients were he felt uncertain in diagnostic or therapeutic policy.

The GP will explain the reason for the Joint Consultation in the presence of the patient as well as the medical history. The specialist, together with the GP, can take history and examine the patient in order to advise the GP on the subsequent policy. As long as the patient is not referred to the outpatient clinic, the GP will retain medical responsibility. 


\section{Educational effects}

The experiences of Jaint Consultation on several medical fields and with different sorts of patients have been documented in randomised studies. Although every medical field had its own emphasis, many results concord. After two years of Joint Consultation, participating GPs referred $10 \%$ less patients to the orthopaedic surgeon and the cardiologist. For the field of rheumatology, this reduction in referral rate even amounted to $62 \%$, which was, amongst other things, due to different inclusion criteria (no Joint Consultation if the GP had a question on the patient, but strictly as alternative for referral). It seems that these results are due to learning effects of GPS.

A redistribution of referred patients occurs because of these educational effects. On one hand, referrals are avoided, on the other hand, through more knowledge, referrals are generated. So, there is a better selection of patients that remain under the medical care of the GP and of patients that are referred to the secondary health care level. At the end of the day, the number of referrals decreases. Of those patients that are presented in a Joint Consultation session, only 15 to 35 percent are subsequently referred to the outpatient clinic.

In most cases, a single Joint Consultation session is sufficient for the GPs to treat the patients from there on independently. When monitoring the general health status of patients after Joint Consultation, the quality of health status proves to be similar to the usual care. Patients in general are very satisfied with this form of health care delivery. They are being treated within the familiar setting of the practice of the GP with a considerable shorter waiting period and they receive optimal attention during a Joint Consultation session.

Not only patients and GPs benefit from this form of collaboration. The intensive collaboration provides the specialist with insight into the specific characteristics of procedures in primary care and provides mare information about the social context of the complaints of patients. More familiarity with each other's professions is a precondition for better collaboration.

Another striking aspect is the fact that, in comparison to the outpatient clinic, less diagnostic tools are used. This could very well be because during Joint Consultation sessions, the specialist needs to make his judgement and advises more explicit to the GP5 and because during Joint Consultation sessions -working outside of the hospital- he joins in more with the angle from a primary care perspective.

The results of all effects are that the model is cost-effective, despite the time GPs and specialists invest in Joint Consultation sessions. 


\section{Positive}

Even during the study phase, it became apparent that the effects were positive to such extent that implementation would be advisable. The so-called carrousel-model was the consequence. This model has been introduced in North Limburg in 1998; it started in the region of Maastricht in 2001. The purpose is to embed Joint Consultation structurally in the regular health care for as many GPs and different medical fields as possible. Forty-eight GPs and 12 specialist from the fields of cardiology, dermatology, ENT, neurology, orthopaedic surgery, ophthalmology and pulmonology, all working for the Foundation Hospitals North Limburg, gained experience in the region of North Limburg.

Eighty GPs (of a possible 93) participate in the region of the University Hospital Maastricht together with 5 specialist fields (cardiology, pulmonology, orthopaedic surgery, ENT and rheumatology). Finally, in the region Southeast Brabant, the start of a carrousel of Joint Consultations is planned for the beginning of 2002. The procedures are similar to the study phase; GPs are divided in groups of 3-4 and have a monthly Joint Consultation session with an assigned specialist.

The learning effect of Joint Consultation is most formidable in the first year; the second year adds less. The GPS are therefore matched with a certain medical field for the duration of one year (for certain medical fields in North Limburg, the duration was even limited to a half year). Next, the GPs switch medical fields, hence the carrousel-model. This constitutes a permanent collaboration between GPs and specialists. The first results from North Limburg confirm the findings of the study phase.

\section{Workload}

There is great difference between a study-design and implemented health care. The carrousel-model involves more GPs and more different medical fields. Another aspect is that Joint Consultation takes up extra time from both GPS and specialists. And we have to comment on that in particular. GPs who participated in the study phase claim, that the increased knowledge and skill makes it easier (in this case, takes up less time) to treat patients with similar conditions. In short, Joint Consultation, eventually, does not increase the workload for GPs. From the perspective of the specialists, one could argue that through Joint Consultation the number of patients referred to the outpatient clinic decreases, and the time invested in Joint Consultation session would be compensated by time saved at the outpatient clinic. Because of the surplus of patients at the outpatient clinic, 
specialists will hardly notice the effects from Joint Consultation, besides decreasing waiting lists.

\section{Conditions}

Despite above-mentioned reasons, we believe that financial compensation is an absolute condition for successful integration of Joint Consultation in the regular health care. GPS and specialist need to be compensated for the time and effort they put in Joint Consultations. This has been achieved for the Mastricht situation in collaboration with the local health insurance company VGZ. Financing elsewhere is still project-based.

The educational effect of Joint Consultation is also recognised; all GPS get accreditation for their participation. Not just accreditation and compensation are determinative factors. Reporting is not a primary goal, but is necessary for the purpose of patient files. An adequate report has to be available for both GPs and -in case of referral- specialists at the outpatient clinic. This demand is being met by a co-ordinator who gathers the reports and who supplies those to the parties involved. Furthermore, the co-ordinator acts as adviser for the participating physicians and patients.

\section{Future}

A start has been made for the introduction of Joint Consultation as a part of regular health care both an academic (Maastricht) as a peripheral setting (northern Limburg, south-east Brabant). The preliminary findings are exceptionally positive for a successful implementation. Adaptations are still possible on a regional level. Firstly, the number of medical fields and the number of GPS can be expanded. Further, the infrastructure of collaboration can be used for example for the introduction or integration of general practice bound nurses or nurse practitioners. A transmural initiative such as this can be integrated in the regular system of medical fees through rates for GPs and rates for specialists.

Eventually, we aim to motivate and support other regions in similar methods of collaboration.

Finally, Joint consultation should be rewarded with a place in regular educational programs as it meets the demands of continuous professional development to a high degree.

Joint Consultation makes the perspective of GPS as the "spider in the web" of health care more realistic. 


\section{References}

1. Schulpen GIC, Vierhout WPM, van der Heijde DM, Landewe RB, van der Linden 5, Winkens RAG. De waarde van een gezamenlijk consult van huisartsen en reumatologen bij patiênten in de eerste lijn. Ned Tijdschr Geneeskd 2003;147:447-450.

2. Schulpen GJC, Vierhout WPM, van der Heijde $D M$, Landewé RB, Winkens RAC, WesselinghMegens AMK, et al. Joint Consultation of General Practitioner and Rheumatologist: Does it matter? Ann Rheum Dis 2003;62:159-161.

3. Vierhout WP, Knottnerus $J A$, van ooj $A$, Crebolder $H F_{*}$ Pop $P$, Wesselingh-Megens $A_{i}$ et al. Effectiveness of joint consultation sessions of general practitionel's and orthopaedic surgeons for locomotor-system disorders . Lancet 1995;346:990-4.

4. Vierhout WPM. Het Gezamenlijk Consult van huisarts en specialist in de eerste lijn. Amsterdam: Thesis Publishers; 1994.

5. Vlek $H$. Cardiologue. Joint consultation of general practitioners and cardiologists in a primary care setting. Maastricht: Datawyse; 2000 .

6. Vlek JFM, Vierhout WPM, Knottnerus JA, Schmitz JJF, Winter J, Wesselingh-Megens AMK, et al. A randomised controlled trial of joint consultations with general practitioners and cardiologists in primary care. Br J Gen Pract 2003;53:108-112. 
Chapter 8 


\section{Discussion}

In the introduction of this thesis, we stated the research questions, which were formulated at the beginning of the project. In this chapter we will discuss the advantages and disadvantages of Joint Consultation based on the findings of the studies to address these research questions. First, we stated that a conditio sine qua non for the success of Joint Consultation, were the health status and the feasibility. Patients' health status should absolutely not be compromised by the fact that they were being treated in an alternative setting (the GP's practice instead of the outpatient clinic). Subsequently, Joint Consultation constitutes a meeting of 4 doctors on a six-weekly basis where, apart from the host-GP, the other participating physicians (as well as the patients) needed to travel to that one location. In short, with busy agendas and Joint Consultation being potentially time-consuming, practical feasibility needs to be achieved. A cost evaluation is essential to "justify" the seemingly extra effort.

We used the Joint Consultation as an alternative for referral; in other words. we treated patients in a primary care setting who normally would have been referred to the outpatient clinic. Both the intervention as the control group patients received follow-up during one year after their initial consultation with their GP. During that year, they were monitored with monthly Euroool questionnaires. Analysis of these data showed no significant difference between the two patient groups with respect to the health status. This complies with the findings of the participating GPs, as there were no patients who required a secondary referral to the outpatient clinic (after follow-up of Joint Consultation). Furthermore, patients indicated, both after the consultation and after one year of follow-up, to be satisfied with Joint Consultation in the same degree as patients were satisfled with the outpatient clinic. This applies also to the reassurance after either a consultation at the outpatient clinic versus a consultation in a Joint Consultation session. Taking these objective and subjective observations into consideration, we may conclude that from a patient satisfaction perspective and a safety perspective, Joint Consultation was at least comparable to the outpatient clinic.

As for the aspect of feasibility, we had some previous experience in the organisation of Joint Consultation sessions and the subsequent evaluation. So, as expected, no insuperable difficulties have occurred. Furthermore, analysis of costs demonstrated that, when taking the effects of Joint Consultation into account, overall costs are even less in Joint Consultation than during regular care at the outpatient clinic.

In conclusion, both prerequisites were met. 
The results for GPS, rheumatologists and general health care were evaluated subsequently. These evaluations turned out to be positive. The GPs referred significantly less, rheumatologists used less diagnostic tools and less follow-up consultations, and aspects of communication between doctors showed improvement. The initial extra time invested and therefore money invested, turned out to, eventually, time saved and perhaps equally important money saved. Unfortunately, since there are long waiting lists for the outpatient clinic of rheumatology, the time saved would (at first) only result in shorter waiting lists. As for the GPs, they have indicated that loint Consultation increases their skill, which enables them to be more effective and thereby save them time on other patients.

In short, evaluating the initial research questions, all requirements were met and all participating parties seem to gain.

How to put these findings in the perspective of national health care and even international health care?

\section{National health care}

First, we need to realise that this was a study in a certain setting, with a limited number of participants, with a specific medical field and many other situational limitations.

Before discussing these limitations in detail, we need to focus on one aspect of importance when extrapolating the study findings. Fortunately, we were able to implement Joint Consultation in the region of Maastricht as of September 2001. This implementation has taught a few lessons. Principally, it taught us that implementation is possible. Of all possible participants in primary care, $86 \%$ of the GPs actually participated and after one year (and changing medical fields) still continue to participate. The same applies to the specialists.

Does this imply that Joint Consultation can be implemented everywhere in the Netherlands?

That statement would be too bold. We have found that the willingness to participate is essential. Other regions who do not know the concept of Joint Consultation nor have had experience with it, may be more reluctant. GPS are more and more overwhelmed by their workload and are increasingly expectant and critical to initiatives that they perceive as time-consuming. This applies for specialists as well, together with the fact that whereas specialists working academically are in the pay of the hospital, specialists in non-academic hospitals are paid based on fee for service. In other words, a financial reason for maintaining high referral rates may exist. On the other hand, many physicians strive for quality in health care, not to forget the waiting lists which is an 
increasing problem in the Netherlands for many medical fields. Better communication, collaboration and improvement of health care quality motivates specialists to participate, as has been demonstrated in a peripheral hospital in Venlo where the Carrousel model first started. Still we believe that noble motivation is not sufficient. In our implementation, we chose to financially compensate both CPS and specialists. Furthermore, Dutch physicians need to acquire accreditation for professional educating and this is provided for the participating GPs. We think that these compensations hold more success for maintaining motivation in the long run.

When discussing Joint Consultation through publications and presentations, we experience two types of reactions on a national level:

1. More and more initiatives are started in different regions in the Netherlands for "Joint Consultation"-like models of collaboration. This demonstrates a need for these types of collaboration. Our results and experience have been welcomed to further these projects. Besides enthusiastic GPs and specialists, health care insurance companies in other regions have been positive in funding these projects as well. So, on one hand we have our own success in implementation and several national initiatives.

2. On the other, we also encounter scepticism when presenting our findings. Joint Consultation, especially at first sight, seems very time-consuming and therefore hardly motivating. It seems that the gap between CPs and specialists over time has become too great to easily be bridged. Finally, a practical and, unfortunately, very realistic objection is the financial compensation. This part has proven to be important in winning people over to participate, but not all health insurance companies are currently willing (or able) to finance Joint Consultation models.

Scientific and societal debates are remarkably unanimous on the need for patient centred care, better collaboration between primary and secondary health care levels, disease-management or shared care models. From that perspective Joint Consultation is supported. However, the Dutch health care system provides little to no means to (structurally) finance Joint Consultation (or similar health care innovation) projects. For both GPs and specialists, no rates are available for e.g. Joint Consultation. Even more so, the current system of remuneration of specialists is purely based on the quantity of hospital related medical actions (number of consultations, diagnostic and therapeutic tools). Unfortunately, all discussions on changing health care rates are based on new prices on old products. This still leaves innovation financially in the cold.

Any form of transferring care, whether it is to nurse practitioners or to other physicians, is consequently "a loss of income". A national debate on the desire for 
transferring and sharing care needs to result in a modus for financial compensation which is superposed on the existing rates.

Only then, models as Joint Consultation have a chance of permanent implementation.

\section{International health care}

Dutch health care holds some fundamental differences with most international health care systems. One of the most characteristic features is the role of the GP. General practitioners are primarily responsible for the medical care and GPs are the ones who decide on referral. In other words, generally patients only consult specialists after a referral by their GP. This gatekeeper role enables GPS to influence patient flows through Joint Consultation. Obviously, this is not the case in most countries where patients consult specialists on their own initiative. Joint Consultation in those cases would not result in such an impact on referral rates and follow-up policy as in the study. As discussed for the national health care situation, financial motivations are important and internationally, most doctors are paid fee for service. All these factors combined would render Joint Consultation less usable outside the Netherlands. Nevertheless, Joint Consultation does have additional value internationally. We are absolutely not the first to introduce health care substitution models. Many health care systems are experimenting or even implementing health care substitution by specialised nurses. Joint Consultation offers a (complementary) substitution model with a central role for substitution from specialist to GP. This form of substitution might be more logical for health care systems where the GP holds a more dominant role, but still it holds a lesson for all.

The main findings of our study are valid, even beyond the Netherlands, if we consider them somewhat more abstractly. The lessons would be that it seems feasible to enhance the role of GPS as clinicians on the field of rheumatology (and other medical fields for that matter). That it is feasible to change the setting of health care without compromising the quality. That communication between doctors can be improved through better communication and understanding. And that some of the diagnostic policy of rheumatologists can be debated.

Besides the direct results of Joint Consultation, the concept on itself can contribute to the international debate on shared care, disease management and health care substitution.

Many health care systems are confronted with problems in capacity both financially and in manpower. Ageing of the population, increasing diagnostic and therapeutic possibilities, growing public awareness and demand, necessitate change. Change in the form of influencing patients flows, change in the form of 
more collaboration. Especially in chronic conditions such as many rheumatological conditions, many health care providers are involved. In order to maintain a manageable heaith care system, which safeguards health care quality, meets increasing demands and remains affordable, Joint consultation can contribute to the debate without literally being transferable to many ather health care systems.

All things considered, we recommend Joint Consultation as a successful model of collaboration. The results of this study hopefully inspire and convince others to initiate simillar projects. We advise initiators to benefit from the experience and scientific data we have gathered. We also hope that administrators will be inspired and convinced to create transmural rates for proven feasible and successful health care innovation modells. Only then, Joint Consultation will be able to find a definitive place in Dutch and international health care. 


\section{Samenvatting}

Het gezamenlijk consult van huisartsen en reumatologen is een samenwerkingsverband tussen de eerste en de tweede lijn. Dit samenwerkingsverband bestond uit een zeswekelijkse bijeenkomst van drie huisartsen samen met een bezoekend reumatoloog om gezamenlijk patiënten te bespreken die de huisartsen wilden verwijzen, en tot een beleid te komen. Gedurende twee jaar hebben 17 huisartsen en 6 reumatologen hier aan deelgenomen en zijn in totaal 166 patiënten in de studie ingesloten. De primaire vraagstellingen van deze studie, zoals beschreven in hoofdstuk 1, hadden betrekking op de effecten van het Gezamenlijk Consult tussen huisarts en reumatoloog voor patiënten, huisartsen, reumatologen en algemene gezondheidszorg. Hierbij diende het Gezamenlijk Consult een minimaal evenredige gezondheidstoestand voor patiènten op te leveren in vergelijking met de reguliere zorg op de polikliniek en diende het Gezameniijk Consult (logistiek) haalbaar te zijn.

Hoofdstuk 2 beschrijft de effecten van het Gezamenlijk Consult op het verwijsgedrag van de huisartsen die deelnamen ten opzichte van niet deelnemende huisartsen. Na twee jaar aan het Gezamenlijk Consult te hebben deelgenomen, verwezen de deelnemende huisartsen $62 \%$ minder patiënten dan collega's die niet deelnamen. Deze daling in verwijzingen was niet toe te schrijven aan het feit dat de huisartsen verwezen naar andere vakgebieden zoals neurologie, interne geneeskunde of orthopedie. De verschillende diagnoses werden in groepen ingedeeld volgens de zogenaamde Standaard Diagnose Registratie. Hoewel de diagnoses in aantallen daalden, bleven de groepen in verhouding even groot ten opzichte van elkaar. De enige uitzondering hierop was de groep fibromyalgie; deze daalde relatief méér dan de andere diagnoses.

In hoofdstuk 3 werden de diagnoses van de huisartsen nader bekeken. In $64 \%$ van de gevallen bleek de reumatoloog het niet eens te zijn met de diagnose van de huisarts. Wel werd opgemerkt dat als de reumatoloog het eens was met de huisarts over de diagnose, de reumatoloog het ook vaker eens was over het beleid bij de patiënt. Een juiste diagnose blijkt dus van belang te zijn. Dit lijkt logisch, maar huisartsen werken vaak meer vanuit de symptomen van patiënten dan vanuit de diagnose.

Tevens werd de diagnostiek en therapie door de huisartsen en de reumatologen beschreven. Voor de diagnostiek viel op dat de reumatologen bij een gezamenlijk consult veel minder diagnostiek (voornamelijk bepalingen in bloed en röntgenfoto's) gebruikten dan op de polikliniek. Bij het gezamenlijk 
consult gebruikten de reumatologen in $56 \%$ van de gevallen géén diagnostiek ten oprichte van $22 \%$ op de polikliniek. De therapie die de reumatologen inzetten verschilde niet tussen gezamenlijk consult en poli. Een ander opmerkelijke verschil tussen gezameniijk consult en de poli was het aantal vervolgconsulten. Een eenmalig consult door de reumatoloog bij het gezameniijk consult vond plaats in $85 \%$ ten opzichte van $35 \%$ op de polikliniek; de reumatologen spraken dus meer vervolgconsulten af bij de patiënten die ze te zien kregen op de poli. Tenslotte werd in dit hoofdstuk de tevredenheid van de patiënten en de algemene gezondheidstoestand van patienten (zowel in het begin van de studie als na één jaar) gemeten. De tevredenheid met de poli was gelijk aan de tevredenheid na een gezamenlijk consult. De gezondheidstoestand verschilde ook niet tussen de twee situatiles. Kortom, de diagnoses, diagnostische middelen en het beleid verschilde nogal tussen huisarts en specialist en tussen gezamenlijk consult en de polikliniek, maar dit ging niet ten koste van de tevredenheid en de gezondheid van de patiënten in het gezamenlijk consult als we het vergelijken met de poli.

De communicatie tussen artsen en patiënten en tussen huisartsen en reumatologen wordt in hoofdstuk 4 gepresenteerd. Een aantal gegevens valt op in de resultaten. Dit is op de eerste plaats de communicatie tussen huisarts en patiënt. De patiënten gaven hun bezorgdheid aan en de mate van ernst die zij hun klacht toedichtten. Ook de reden van het bezoek bij de huisarts werd aangegeven. De huisartsen moesten aangeven hoe zij dachten dat de patiënt over de genoemde zaken dacht. Dit verschilde behoorlijk; bij de reden van het huisartsbezoek kwam de reden zoals de huisarts dacht dat deze was slechts in $39 \%$ van de gevallen overeen met de reden die de patiënten daadwerkelijk aangaven. Hoewel de patiënten aangaven wel genoeg aandacht te hebben gehad $(76 \%)$ en genoeg uitleg te hebben ontvangen $(62 \%)$, gaven ze ook te kennen in $43 \%$ totaal niet gerustgesteld te zijn. De communicatie is ook bekeken tussen huisarts en reumatoloog. Hier gaven de huisartsen de reden voor verwijzing aan en moesten de reumatologen aangeven hoe zij de reden van verwijzing hadden ervaren. Ook hier was de overeenstemming $39 \%$. Wel gaven de reumatologen aan gedurende het gezamenlijk consult veel meer informatie te ontvangen van cle huisarts over de patiënt $(57 \%)$, die uiteindelijk ook het beleid van de reumatoloog belangrijk beïnvloedde, dan bij de polipatiënten (15\%). De reumatologen gaven ook aan of zij vonden dat de verwezen patiënt door de huisarts zelfstandig had kunnen worden afgehandeld. Bij de patiënten op de polikliniek vond de reumatoloog in $96 \%$ dat de huisarts de patiënt zelf had kunnen behandelen ten opzichte van $43 \%$ bij de patiënten van het gezamenlijk consult. Klaarblijkelijk leidde het gezamenlijk consult tot meer begrip voor de verwijzing ten opzichte van de reguliere verwijzing naar de polikliniek. 
Hoofdstuk 5 beschrijft een ander aspect van de route van de patiëntenzorg, namelijk de poliklinische zorg. Het gezamenlijk consult zou mogelijk als middel kunnen dienen om patiënten van de polikliniek terug te verwijzen naar de huisarts. Normaal gesproken is als een patiënt ontslagen wordt van de poli (naar de zorg van de huisarts) verdere controlle ook niet nodig. Het idee achter de terugverwijzing via het gezamenlijk consult was dat die patiënten die wel medische controle nodig hadden, maar waarbij de reumatoloog geen meerwaarde had in de controle, ook door een huisarts actief gecontroleerd zouden kunnen worden. Het gezamenlijk consult zou als middel dienen om de patiënten door de reumatoloog aan de huisartsen over te dragen. Van de 17 deelnemende huisartsen waren 276 patiënten bekend op de polikliniek. Hiervan werden 21 in de studie ingesloten. Dit aantall was zo gering omdat 121 ontslagen waren van de poli, 87 kwamen niet in aanmerking omdat deze wel degelijk specilalistische follow-up nodig hadden, 22 patiënten weigerden deel te nemen en 6 patiënten werden niet ingesloten door de behandelend reumatoloog.

De studie naar de terugverwijzing heeft dus wel inzicht verschaft in hoe de patiëntenstromen nu precies verlopen, maar gaf ook aan dat de rol van het gezamenlijk consult hierin beperkt is.

De kosten van het gezamenlijk consult ten opzichte van de kosten van de gebruikelijke behandeling op de polikliniek zijn beschreven in hoofdstuk 6 . Deze kosten werden beschouwd vanuit een integraal perspectief, waarbij alle kosten die daadwerkelijk zijn gemaakt in de studie maximaal worden meegerekend (iedere huisarts in een gezamenlijk consult en de alle kosten van de reumatoloog inclusief overhead en dergelijke) en vanuit een marginaal perspectief. Dit marginaal perspectief kende een aantal uitgangspunten; namelijk dat in een gezamenlijk consult slechts één huisarts financieel wordt meegeteld (de andere twee zijn aanwezig voor nascholingsdoeleinden) en dat de overhead van het ziekenhuis bij de reumatoloog in het gezamenlijk consult niet meetelt. De integrale kosten voor de polikliniek bedroegen 313 euro's per patiënt ten opzichte van de integrale kosten van 529 per patiënt voor het gezamenlijk consult. De marginale kosten van het gezamenlijk consult bedroegen 236 euro's per patiënt.

Als we echter de daling in verwijzingen en de daling in het gebruik van diagnostiek voor de gezamenlijk consult groep meerekenen dan worden de kosten als volgt. Per verwijzend huisarts zijn de integrale kosten 5388 euro's over de studieduur van twee jaar ten opzichte van 5167 euro"s voor de integrale kosten van het gezamenlijk consult. De marginale kosten zijn op deze manier 2130 euro's per huisarts over twee jaar. Kortom, met de effecten van gezamenlijk consult meegenomen, zijn de kosten voor het gezamenlijk consult zowel 
integraal als marginaal lager dan de kosten van de poli. Er kan dus zelfs een maximale besparing van $62 \%$ worden gerealiseerd.

Hoofdstuk 7 geeft vervolgens een overzicht van de verschillende studies naar het gezamenlijk consult in de loop der jaren en de uiteindelijke implementatie hiervan. In de regio Maastricht is het gezamenlijk consult namelijk als "Carrousel gezamenlijke consulten" in de reguliere zorg opgenomen. Van de 92 huisartsen nemen hier 80 aan deel samen met 5 verschillende specialismen (KNO, orthopedie, cardiologie, longziekten en reumatologie). ledere huisartsengroep wordt gedurende éen jaar aan een specialisme gekoppeld om na een jaar van onderwerp te veranderen. De voorwaarden en ervaringen worden in dit hoofdstuk beschreven.

Samenvattend toont dit proefschrift de ervaringen en bevindingen van het gezamenlijk consult van huisartsen en reumatologen. De verschillende invalshoeken laten positieve resultaten zien op het gebied van verwijzingen, communicatie, beleid, poliklinische follow-up, kosten en implementatie. Hopelijk kan dit proefschrift bijdragen in de discussie rond de effectiviteit van transmurale samenwerking, de verschuiving van taken en het integreren van zorgverlening.

Guy Schulpen 


\section{Dankwoord}

Bij een multidisciplinair onderzoek als het gezamenlijk consult is het vanzelfsprekend dat er veel mensen betrokken zijn geweest.

Ik wil op de eerste plaats prof. Van der Linden danken voor de kans die ik heb gekregen bij de werkgroep reumatologie en het vertrouwen dat in mij is gesteld. Desirée van der Heijde, Robert Landewé en Annelies Boonen wil ik bedanken voor hun begeleiding in analyses en bij het schrijven van de artikels. Niet alleen bovengenoemde reumatologen hebben met veel enthousiasme als consulent gefungeerd, maar ook Debby Vosse, prof. Geussens en Marijke van Santen. Klaarblijkelijk hebben de huisartsen veel van jullie opgestoken en waren de huisartsen unaniem in de tevredenheid met jullie samenwerking.

Deze huisartsen die trouw (soms onder aansporing van Annemie Wesselingh) de vragenlijsten invulden en de gezamenlijke consulten terdege organiseerden wil ik graag met naam noemen; de huisartsen Warnier, Vaissiers, Smits, Theunissen, Meijer, Heijen, Priem, Dangê, Prevoo, Keijsers, Keijsers-Peters, de Jong, Wiertz, Ritzen, Swaans, Ausems en Habets. Ook mocht ik me verheugen samen te werken met een grote groep bereidwillige patiënten die bijzonder compleet en tijdig hun vragenlijsten invulden.

Dan de twee mensen die in het onderzoek voor mij het belangrijkst waren. Nandus Vierhout heeft het gezamenlijk consult bedacht in de jaren tachtig en is er zelf op gepromoveerd. Hij heeft mij de kans gegeven het verder te ontwikkelen onder zijn uitermate plezierige begeleiding. Jouw relativeringsvermogen is geweldig en de samenwerking met jou altijd prettig. Vervolgens Annemie Wesselingh, mijn research-assistente. Jouw werkijver was de motor achter het gezamenlijk consult en nu je coördinator van de Carrousel gezamenlijke consulten bent des te meer. Werken met jou is ook persoonlijk en daarom hoop ik nog lang met je samen te werken.

Ik wil de collega"s in onderzoek bij reumatologie bedanken voor de prettige samenwerking en de genoeglijke uurtjes "spuien".

Het Gezamenlijk consult bleek zowel qua onderzoek als voor de implementatie moeilijk te financieren te zijn. Dit is geillustreerd in het feit dat het Gezamenlijk Consult Huisarts-Reumatoloog uiteindelijk door 4 verschillende bronnen is gesubsidieerd en het gegeven dat de Carrousel Gezamenlijke Consulten pas acht jaar na het proefschrift van Nandus gestalte heeft gekregen. Een woord van dank is dan ook wel zeer op zijn plaats voor Hans Fiolet. Deze heeft de financiering van de Carrousel verzorgd en de afronding van de promotie gegarandeerd. Bovendien heeft hij met de afdeling Transmurale Zorg een nieuwe weg in de gezondheidszorg ingeslagen. Deze nieuwe weg bleek gedurende mijn 
promotie zo aansprekend dat ik mijn carrière hiernaar heb verlegd. Dank voor de kansen die je hierin hebt geboden.

Ik wil vervolgen met diegene die me, naast de werkgroep reumatologie, hebben geholpen bij verschillende artikels; Ron Winkens, Harry Crebolder, Hans Vlek, en Hans Severens.

Hierbij hoort ook de onderzoeksgroep en andere collega's van BZe VII: jullie creërden een sfeer die het werken aangenaam maakt.

Vervolgens wil ik mijn paranimfen bedanken; Bart, we zijn samen aan de wetenschap begonnen, waar je mij inmiddels qua tempo achter je hebt gelaten. Ik hoop je snel weer in te halen en ik zal je missen nu je weg gaat. Remember, whenever in doubt go 5outh. Yolande en ik hebben jarenlang een kamer gedeeld bij het T\&DC (en later Bze VII) en dus weet zij als geen ander hoe dit proefschrift tot stand is gekomen. De lol die we hebben gehad hebben me af en toe over eem dood punt heen geholpen en staan absoluut in mijn geheugen gegrift.

Ik reken mezelf rijk met de vrienden die ik heb en zodat ik niemand oversla benoem ik ze hierbij allemaal; er is meer in het leven dan alleen werk en jullie vormen een belangrijk deel van mijn leven.

Mijn vader en moeder wil ik bedanken voor hun niet aflatende steun. Mijn thuis bij jullie is de basis geweest van alles wat ik belangrijk acht. Béryl, tja je bent me net voor geweest.

Dan ik wil besluiten met de twee mensen die de meest centrale plek in mijn leven innemen. Mascha, ik houd van jou; één en éên is in dit geval één.

Sam, ontzettend stoere vent, je bent het beste wat me is overkomen. 


\section{curriculum Vitae}

De schrijver van dit proefschrift werd geboren op 3 juli 1972 te Roermond. In 1990 haalde hij zijn WWO diploma aan het Strabrecht College te Geldrop. In hetzelfde jaar startte hij met zijn studie Geneeskunde aan de Universiteit Maastricht. Hier behaalde hij in 1995 het doctoraall examen en in 1998 het artsen examen. De eerste onderzoekservaring werd opgedaan via de Universiteit Leiden in een studie naar de prevalentie van schistosomiasis in de bevolking van Lagdo, Kameroen. In 1998 startte hij met de promotiestudie bij de vakgroep reumatologie van het academisch ziekenhuis Maastricht. Sinds 2001 is hij aangesteld als arts-onderzoeker bij de afdeling Transmurale Zorg (BZe VII) van het academisch ziekenhuis Maastricht. Binnen deze functie is hij betrokken bij verschillende zorgvernieuwingsprojecten. 